\title{
The Political Economy of Ownership: Housing Markets and the Welfare State
}

\author{
IPES Conference Madison 2011 \\ Ben Ansell, University of Minnesota
}

\begin{abstract}
The major economic story of the last decade has been the surge and collapse of house prices worldwide. Yet political economists have had little to say about how this critical phenomenon affects citizens' welfare and their demands from government. This article develops a novel theoretical argument linking housing prices to social policy preferences and policy outcomes. I argue that homeowners, particularly those experiencing rapid house price appreciation, will become less supportive of social insurance policies since their houses act as a form of self-supplied private insurance against job and income loss. Political parties that represent homeowners will, following these preferences, cut social insurance spending substantially during housing booms. This is particularly apparent in those countries that saw large capital inflows accompanying their housing booms. I test these propositions using both micro-data on social preferences from surveys in the USA, UK, and Germany, and macro-data of national social spending for 18 countries between 1975 and 2001.
\end{abstract}

This article represents an extension of ongoing work currently under review. Please do not cite without permission. 


\section{Introduction}

The past few decades have seen a remarkable transition in the political economies of the advanced industrial world. Whereas in the postwar era, the Keynesian duel of rapid price inflation and full employment held sway, since the 1980s inflation in the price of goods and services, and concomitantly in wages, has been held at bay. During the same time period, however, a new source of volatility, dormant since the Great Depression, has re-emerged - that of the price of assets, such as housing and equities. Between 1985 and 2006 real house price inflation was three times greater than between 1970 and 1985, and had a substantially higher level of volatility. The housing boom and bust that played out between 2002 and 2009 was unprecedented in modern times. Moreover, there has been ever-greater 'leakage' from the housing sector into the health of overall economy. The IMF (2008) estimates that in several countries, including the USA, shocks to house prices and their feedback into consumption and residential investment now account for over twenty percent of variation in national economic output.

Such volatility is not a phenomenon affecting only participants in high finance. Surges and collapses in the price of assets threaten the livelihood of most citizens and underpin, or threaten, their savings and personal wealth. Politicians have responded everywhere to the increased importance of assets in determining citizens' welfare. In boom times there emerge declarations of an "ownership society", in bad times, politicians fret about collapsing asset prices. These reactions suggest that asset prices have profound effects both on citizens' welfare and on policymaking. However, to this point, social scientists know very little about how changes in asset prices, such as housing, affect support for the broader institutions of social policy. This neglect is surprising considering the importance of housing values to both individual well-being and macroeconomic health. The contemporary significance of housing markets provokes two questions in particular. First, how do citizens respond to house price growth or decline in terms of their demand for social insurance and redistribution? Second, how do governments, and the political parties that seek office in them, respond to house price changes in terms of social policy? 
Political economists come to these questions armed with analytical weapons from an earlier war. The focus of political economy has been on the labor market - to the exclusion of the asset market - both in terms of the micro-preferences of citizens over social insurance and in terms of policymaking at the national level. Early work on both individual preferences and on government spending outcomes emphasized the role of social class as defined by labor market income (Goldthorpe, 1968; Korpi, 1983). More recently, a consensus has emerged on the importance of individual labor market risk - be it skill specificity (Iversen and Soskice, 2001), occupational risk (Rehm, 2009; 2011), or income volatility (Hacker, 2006) - in determining social policy preferences and policy outcomes. Yet, the focus on individual level risk as determining demand for social insurance has led scholars to overlook the capacity of individuals to supply their own private insurance, through the ownership of assets, as a hedge against labor market risk. In a world of volatile asset booms and busts and widespread homeownership, this neglect is problematic, as citizens increasingly rely on their houses and other assets as 'nest eggs' for retirement or loss of income. Incorporating the ownership of assets complicates and enhances the dominant way that the political economy literature has conceived of the state-market nexus.

In this paper I provide a novel theoretical framework for the impact of asset ownership focusing on housing - on social insurance policies. I begin in Section Two by discussing the implications of thinking about asset markets for theorizing about the preferences of individuals over particular social policies. I argue that when asset prices are rising, the policy preferences of asset-owners diverge quite substantially from those predicted by standard political economy theories that are based on labor market status. Rising house prices, for example, make homeowners less supportive of publicly provided social insurance and pensions since the value of their 'private insurance' increases. Collapsing house prices and negative equity, in contrast, produce demands for government support. I argue that political parties will respond to these changes in voter preferences and that this effect will be pronounced for right-wing parties, which disproportionately represent homeowners. 
The following two sections develop the empirics of home ownership and social policy. Section Three begins at the micro-level, focusing on individual preferences over social policy using a series of social surveys in the USA, England, and Germany. I examine how the preferences of homeowners over social policy change over time according to the prevailing level of house prices. In the case of the USA, I also examine how the estimated rate of appreciation individuals have experienced since they purchased the house affects their policy preferences. Throughout these examples I find powerful and robust effects of ownership and house prices on policy preferences, particularly among right-wing voters. But do these preferences matter in any substantive sense for actual policymaking?

I turn in Section Four to examining the effects of changes in aggregate house prices on national social insurance policies. Here I examine the joint effect of political partisanship and house price changes on general social spending and transfers, pensions spending, and unemployment benefits. I find a powerful conditional effect where right-wing government combined with house price growth reduces government spending dramatically, controlling for a broad range of macroeconomic conditions. The pattern is particularly pronounced in countries with higher homeownership rates. This effect, hitherto undiscovered in the literature on the determinants of public spending, demonstrates the significance of a deeper understanding of the role of ownership in political economy. Section Five examines the role of global capital flows in determining this relationship, following the insights developed in Broz (2010), showing that the partisan effect appears strongest in countries that experienced current account deficits and (hence) large capital inflows. Section Six concludes with some implications of the theoretical approach developed in this paper for rethinking a range of anomalies in comparative and international political economy. 


\section{A Theory of Asset Ownership, Asset Prices, and Social Spending}

Political economists know a great deal about the determinants of social policy preferences and outcomes in the postwar era. The theoretical apparatus developed by several cohorts of scholars was built on the role of labor market in defining both individual preferences and the behavior of political parties. This focus on the labor market was not surprising. The postwar world was one where macroeconomic policies had larger effects on the product and labor markets -in terms of prices, wages and employment - than they did on the value of assets like equities and housing. Citizens relied almost entirely on wages for their income, and on employeror government-provided unemployment benefits or pensions for periods where they were out of the labor force, either through involuntary unemployment or voluntary retirement. Power resources theory provided powerful insights into the postwar world of economies dominated by the manufacturing sector. This work argued that social class, as defined by an individual's job, determined citizens' demands for greater or lesser government spending (Goldthorpe, 1968). Social class also determined the behavior of parties, with left-wing governments, supported by the working class, increasing social insurance spending. (Korpi, 1983).

As the economic structure of developed countries shifted towards the service sector and knowledge-intensive production sector, recent work has moved away from class cleavages to focus on the particular skills individuals bring to the labor market. Here work has examined both how skills affect policy preferences (Iversen and Soskice, 2001) and how governments of various partisan stripes and differing national institutions provide these skills (Boix, 1998; Estevez-Abe, Iversen, and Soskice, 2001; Ansell, 2010). At the micro-level, Iversen and Soskice (2001) argue that the relative specificity of an individual's skills will determine the risk they face in the labor market and shape their preferences over government policies that insure them against income loss. Thus individual risk conditions the demand for social insurance. At the macro-level of analysis, labor market risk is considered to underpin national social policies, whether that risk is produced by specific skills (Estevez-Abe, Iversen, and Soskice, 2001; Mares, 2003; Iversen, 
2005), occupational risk (Rehm, 2011), or by exposure to volatile global trade and capital flows (Garrett, 1998; Rodrik, 2000). Although class cleavages have been supplemented by a more refined analysis of skills and risk, most political economists still view both policy preferences and policymaking as at root defined by how the labor market shapes the demand for social insurance.

While the structural shift in advanced industrial economies to labor markets based on services and human capital formation has been incorporated into the political economy canon, the accompanying growth in the macroeconomic importance of asset markets, especially housing, has so far been largely neglected. This is somewhat surprising given the emphasis placed on 'assets' by recent literature. Indeed, Iversen (2005) argues that an investment in human capital produces the most important asset people ever own. For some people this is likely true. However, for many others the most important investment they ever make, their most valuable asset, is not their education but their home. Wealth, in other words, may be just as important as labor market income in shaping an individual's economic circumstances and, by implication, what they demand from government. This is especially true when such wealth is rising, or declining, dramatically as has been the case in global housing markets since 1980.

The implications of housing markets for social policy and individual preferences, while somewhat marginalized, are not entirely uncovered terrain. In terms of the microanalysis of housing and individual preferences, Scheve and Slaughter (2001) examine the role of home ownership in determining trade-policy preferences, arguing that homeowners in regions with uncompetitive industries will oppose free trade deals that might further weaken house prices. There is, however, no existing analysis of home ownership and preferences over social policies, particularly as mediated by house prices. At the macro-level connecting housing markets and social policies, Kemeny (1981), Castles (1998) and Conley and Gifford (2006) have noted the potential tradeoff between homeownership and the welfare state. However, these analyses focus purely on aggregate homeownership rates and, in the case of Conley and Gifford, concentrate on explaining homeownership with reference to social welfare provision rather than vice versa. 
These analyses also do not speak to the role of political parties; rather, there is simply a crosssectional trade-off between homeownership rates and the size of government without analysis into why particular actors within countries want specific policies.

Moreover, the relative price of housing is unexamined in the macro-level analyses, with homeownership assumed to have similar effects regardless of the value of housing. Much as Iversen and Soskice (2001) identify the relative value of skills in particular uses - rather than just the presence of education itself - as key to explaining preferences, if we are to understand the broader impact of homeownership we have to examine the value of the asset of housing itself. Recent work that does take into account fluctuations in the housing market, for example Schwartz (2008) and Schwartz and Seabrooke (2008), remedies this omission but it too does not delve into individual preferences or the behavior of parties, mostly focusing on national-level crosssectional variation. A final gap in work on housing and social policy is that, in contrast to the extensive labor-market literature, scholars have not connected the micro- and macro-levels of analysis. We do not yet know how the preferences of individual homeowners are aggregated into national social policy regimes.

What, then, are these connections between homeownership, housing prices, and social policy preferences and outcomes? As I argued above, the existing literature examining social policy preferences and the provision of social insurance focuses on the demand for social insurance by individuals, according to their labor market risk. There is debate about whether risk comes from skill endowments, occupation, or exposure to trade, but across the welfare state literature there is agreement that individuals facing the risk of losing employment and / or earnings clamor for protection by the state. Political parties, especially on the left, build on these demands, offering policies that protect exposed groups from the ravages of the market. Whether this is phrased as 'decommodification' (Esping-Andersen, 1990), 'compensation' (Garrett, 1998) or 'insurance' (Iversen and Soskice, 2001), the consensus is that social insurance policies emerge as left-wing parties protect risk-exposed individuals from bad labor market outcomes. 
Missing from this analysis of the demand for social insurance is its theoretical and empirical counterpart: the ability of individuals to supply their own private insurance. Where private insurance does figure in the labor market literature it is as a product, such as private health insurance, demanded by richer or lower risk citizens (Hacker, 2004). The literature does not explore the possibility that individuals may be able to 'insure' themselves against income loss by accumulating a supply of tradable assets like housing, regardless of their labor market status. Political economists often think of 'assets' as endowments producing a stream of income in the labor market - for example, thinking of specific skills as an asset that produces different levels of income depending on the use to which it is put. When an individual loses their employment in this model, they also lose the value of the asset. But other types of assets, such as housing, are not tied to the labor market - they exist as a separate stock of wealth. The greater is an individual's wealth, the less they are at risk of a collapse in living standards if they lose their stream of income. Homeownership, thus, acts as a form of self-supplied private insurance against the welfare losses associated with job loss. Consequently, this supply of private insurance reduces the demand for social insurance: private and social insurance are inherently intertwined.

Wealth produced by homeownership - the value of this self-supplied private insurance comes in two forms. First, there is the decision whether to own a house or to rent accommodations. Second, there is the relative value of the house, which may change across time in comparison to the cost of other tradable goods and services. The final level of individual wealth is a product of both of these factors - thus solely examining the effects of being a homeowner without regard to housing prices may be misleading. For example, if house prices are declining homeowners may actually be more supportive of social insurance than are nonhomeowners, particularly if they end up with negative equity. Moreover, differential rates of house price growth will affect the policy preferences of homeowners differently. Homeowners in a boom that rapidly increases their wealth are more likely to feel that they have a large 'nest egg' to fall back on than are homeowners in a country with stagnant home price growth. 
I argue then, that the rate of house price growth will be an important determinant of social policy preferences. For two reasons, when house prices are rising, homeowners will respond by desiring less publicly provided social insurance. First, rising house prices, if taxable, will subject homeowners to higher taxes, which may in part pay for social insurance. Second, and more critically, homeowners have privately insured against income loss due to unemployment or old age by being able to use their homes as a nest egg. Hence they have less demand for public insurance as a hedge against such risks. Furthermore, the greater the growth in house prices, the larger the valuation of this private insurance, implying that support for social insurance should be lowest among those whose houses have had the highest level of real appreciation. Arguably, these responses to rising house prices should be mirrored in the case of decreasing house prices, producing a reversal of preferences. During house price declines, these same individuals should become more supportive of social insurance (or at least, given they may have other sources of income, less oppositional). In summary, I expect homeowners with appreciating property values to demand less social insurance than other citizens, for example renters. Such social insurance includes both insurance against the loss of current income - unemployment benefits or redistributive transfers - and against future income - public pensions. These preferences should be weakened or reversed when house prices decline.

A wrinkle emerges when we examine these claims empirically in that, except for citizens actually selling their house, individuals do not typically see the realized value of their asset. For many individuals their value of their house is a subjective approximation based on information gleaned about the local or national housing market. ${ }^{\mathrm{i}}$ Hence citizens are forming sociotropic impressions of the value of their house and these valuations then determine social policy preferences. This caveat is not especially crucial. First, most studies find that sociotropic voting and opinion formation is more common than pure pocket-book behavior (for example LewisBeck, 1988). Second, many theories of the demand for social insurance also rely on individuals making judgments about uncertain quantities. For example, specific skills arguments, like that of 
Iversen and Soskice (2001), presume individuals are making judgments about the likelihood of finding another job that rewards their skills at the same level as their current occupation. Thus, even though citizens typically do not know the precise value of their house, national, or - even better - local housing conditions will likely shape their estimate.

Given these expectations about how house prices affect the social policy preferences of homeowners, how might these views aggregate upwards into actual policy outcomes? There are two potential mechanisms connecting political parties to the preferences of asset owners and nonowners. The first mechanism is compositional. Broadly speaking, right-wing parties disproportionately represent asset owners. This pattern fits the established findings that homeowners, as well as higher income and older citizens who are more likely to own high-cost housing, tend to vote for right-wing parties (Kingston et al, 1984; Verberg, 2000). As such, during house price booms we should expect right-wing parties to channel the preferences of these constituents for lower social insurance spending. Left-wing parties, with constituent bases that more heavily represent non-owners should not respond in this fashion. The second mechanism is opportunistic. Rather than simply acting as vessels that aggregate the particular preferences of their long-standing constituents, parties may instead come to the table with explicit policy preferences but only be able to enact these when opportunities arise caused by changing public opinion. In this mechanism, right-wing parties would also respond to increasing house prices by cutting social spending but would do so because public preferences had moved in that direction due to the rise in house prices. Since homeowners are a majority in most countries, this would imply the electorate as a whole shifts towards preferring cuts in social insurance during housing booms, advantaging right-wing parties who desire this aim over left-wing parties that oppose it.

The compositional mechanism suggests that the preferences of homeowners are disproportionately important for right-wing parties. Thus empirically, we should expect that during house price booms right-wing governments will cut spending on social insurance policies. The opportunistic mechanism supports this conjecture and has a related implication. Where 
homeownership is higher, homeowners form a larger potential constituency of votes. During house price booms this creates a greater electoral opportunity for right-wing parties to engage in cutting social insurance. Hence, in high homeownership countries the effect of house price booms on right-wing parties reducing spending on social insurance should be amplified. The impact of house price increases on the behavior of left-wing parties is less clear, though generally opposite to that of right-wing parties, since their voting base is made up of both homeowners and nonhomeowners. Finally, these findings at the macro-level will receive greater support if we find their counterparts at the micro-level: it should be the case that the effect of house price appreciation on individual policy preferences is strongest for right-wing voters.

To summarize the theory developed in this section, I have argued that thinking about housing as a form of self-supplied private insurance provides novel insights into both social policy preference formation and policy outcomes themselves. Citizens, relying on housing as private insurance, will be less supportive of social insurance the greater the value of this asset. Political parties will respond to changes in support for social insurance brought about by changes in house prices. In particular, right wing parties, with a support base disproportionately composed of homeowners, will be especially likely to cut social insurance spending during housing booms. These insights complicate the existing consensus in the welfare state literature over how citizens form preferences about social protection and how political parties alter social insurance spending. The existing literature focuses on private risk in the labor market and the role of left-wing parties in responding to risk by providing social insurance. Conversely, thinking about the asset market highlights the role of self-supplied private insurance and the role of right-wing parties seizing on growth in the value of this private insurance as an opportunity to cut social insurance.

\section{The Microfoundations of Asset Ownership and Social Policy Preferences}

I argued above that asset ownership and asset prices should powerfully shape citizens' preferences over social insurance. In this section, I test this conjecture using individual survey 
data - both cross-sectional and panel in form - drawn from three countries that have had quite different experiences with housing prices - the USA, the United Kingdom, and Germany. In each case, I examine how various measures of home ownership and house price appreciation are related to individual preferences over social insurance and redistribution. I find strong and robust evidence for the substitutive effect of home ownership for social insurance under conditions of rising house prices. Put simply, when homeowners experience rising wealth in the form of property price increases they become less supportive of social insurance and redistribution generally. This effect appears to be amplified for right-wing voters, suggesting that right-wing parties will be most responsive to increasing house prices in terms of altering social policies. This section provides empirical microfoundations for the effects of asset prices on citizens' preferences, with Section Four showing how the aggregation of such preferences in political parties then shapes social policy outcomes.

I begin by examining preferences over the funding of the Social Security retirement program in the United States. The USA has a number of data advantages that I draw on in this analysis. In particular, detailed data on house prices, dating back to the 1970s, exist at the local level, allowing a more geographically fine-grained analysis of house prices than is possible with most other national surveys. The American National Election Survey includes questions both on home ownership and on the length of ownership, together permitting the estimation of the house price appreciation experienced by a given individual. However, there are no questions on preferences over unemployment spending nor on redistribution between rich and poor, hence I focus here solely on Social Security spending, following up the other questions in the analysis of the UK and Germany.

I use two datasets the ANES 2004 pre-election dataset and the ANES 2000 to 2004 panel survey. These surveys have three advantages - firstly they directly ask questions about Social Security funding and about home ownership; secondly, 2004 marks, if not the very peak of the US housing boom, a high point on a fairly uninterrupted increase in housing prices; and thirdly, 
the period coincides with a shift in the rhetoric of the Republican party towards what George W. Bush termed 'an ownership society', which would after the 2004 election lead to an attempt by the president to introduce private retirement accounts in lieu of social contributions.

The main dependent variable is a three point scale asking whether individuals would like to see federal spending on Social Security decrease, remain the same, or increase. In the panel analysis I also examine change in this variable, which is accordingly a five-point scale. In terms of independent variables, I examine a variety of indicators of house price appreciation, with the expectation that homeowners who have experienced rising prices will be less supportive of Social Security. I draw on data at the Metropolitan Statistical Area (MSA) and US state level provided by the Federal Housing Administration (FHA). In the 2004 dataset of the 1,039 individuals for whom I have data on the dependent and other control variables, around eighty-five percent live in one of these broadly defined MSAs. For the remaining fifteen percent I have only state level data from the FHA. For the panel dataset MSA data is only available for around one third of respondents, meaning that I use state information for the majority of respondents. The state and MSA house price data is adjusted for consumer price inflation and in many cases dates back more than twenty-five years.

Using this data I construct two types of indicator for the house price appreciation experienced by respondents. For the 2004 cross-sectional analysis I create a variable 'House Price Increase', which combines data on (a) whether an individual is a homeowner, (b) how long they have owned their property, and (c) the percentage change in property values in their MSA or state during the period of ownership. Thus if an individual is a homeowner who has owned a property for five years and the average house price appreciation in their MSA was sixty percent over the period, then they score 0.6 on this index. If an individual is a renter, they score zero. For each individual I create twpversions of this index: (a) their state level score, and (b) their MSA level score where applicable and, where not, their state level score. The latter variable provides the best estimate across all individuals of their house price appreciation - it does however assume that the 
state and MSA level estimates are perfectly comparable. Its mean level in the sample is 0.22 , with a standard deviation of 0.33 and a minimum of -0.18 and a maximum of 2.36. Excluding renters (around $30 \%$ of the sample) the mean level is 0.32 with a standard deviation of 0.36 .

For the 2000 to 2004 panel analysis I no longer employ data on the length of homeownership since in this analysis we are solely looking at the effects of changes in house prices over that four year period on changes in preferences. As above I create a variable that combines information on whether the respondent is a homeowner and the regional increase in house prices. Once more I do this for just state information and for state or MSA information wherever the latter is available.

I include a number of control variables that seem theoretically relevant. One key control is a dummy for homeownership in order to disentangle the effects of rising house prices from homeownership status alone. For other countries, along with a dummy for gender and an age variable, I include a dummy for whether the citizen is retired (and likely on Social Security), a measure of their household income, a measure of their highest level of education, and a measure of their party identification. The latter is clearly a very strong indicator of political preferences in general, including over most forms of social spending. Party identification is a seven-point scale from strong Democrat to strong Republican. Other measures of partisanship, such as a dummy for being a Republican and the George W. Bush 'feeling thermometer' produce near-identical results. Finally, I also use a measure of skill specificity, which Iversen and Soskice (2001) find is a powerful predictor of social policy preferences, particularly with regard to social insurance. I use the NES questions on occupational data and translate this into estimates of individual skill specificity, following the rubric in Cusack, Iversen, and Rehm (2008). Since occupational data is missing for some fifteen percent of the cases, I use multiple imputation to estimate skill specificity for those missing cases. Results without the skill specificity variable or the imputation are very similar, partly because the correlation between house price appreciation and skill specificity is very low (-0.027). 
I begin with a series of ordered logit tests on the cross-sectional 2004 dataset, adjusting the standard errors for clustering by either MSA or state, and using sample population weights provided by the NES. Table One presents a series of models using, in turn, the various measures of house price appreciation. Models One through Four use the data on state house prices and show a robust negative effect of house price appreciation on attitudes towards Social Security. The substantive effect is quite large. Moving from being a renter to owning a house that has doubled in value in real terms is estimated to make an individual around nine percent points less supportive of increasing Social Security spending. This effect is comparable in magnitude to that obtained for gender and much larger than those for income or being retired. Moreover, the effect of estimated house price appreciation is robust to a dummy for homeownership (Model 2), dummies for each state (Model 3) and a particularly stringent specification that includes the homeownership dummy, regional dummies and the five year average level of house price appreciation in a respondent's region (Model 4). This last specification separates out the effect of being a homeowner experiencing house price appreciation from (a) homeownership alone and (b) regional price effects alone. It is the combination of the two that drives preference formation. Models Five through Eight use the MSA or State variable, which should provide more accurate estimates of house price appreciation. The models add robustness checks as in Models 1 through 4 and while very slightly less statistically significant, house price appreciation appears to have a similar effect to the first set of models.

I argued above that right-wing parties are especially likely to seize upon the change in preferences of homeowners over social insurance. Empirically this suggests that the effects of property prices on social insurance preferences should be stronger for right-wing voters. If they turned out to be stronger for left-wing voters that would be anomalous for the theory. In Table Two, I re-examine Models Five and Six of Table One, breaking voters into those who approve of George W. Bush and those who do not (using the fifty percent feeling thermometer threshold as a dividing point). I find strong and robust evidence that it is right-wing voters who are driving the 
results in Table One. Although the coefficients on house price appreciation for Democrats and independents are negative they are not robust at conventional levels. Conversely those for Republicans are highly robust and almost twice the size of those reported for the full sample in Table One. In that sense, Bush's 'ownership society' rhetoric was aimed at his base - right-wing voters are most responsive to the idea of replacing social insurance with a private nest egg.

I now turn to examining dynamic American survey data from 2000 to 2004. Tables Three (a) and Three (b) examine how changes in regional house prices for American homeowners between 2000 and 2004 affected their support for Social Security. Table Three (a) uses just state house price data whereas Table Three (b) adds MSA price data for those citizens who have it. As independent variables I include the estimated house price appreciation for respondents (with renters coded as having experienced zero appreciation) and changes in income, homeownership status, party ID, and retirement status, and controls for the unchanging variables of gender, race, and age (the latter of course changing in a completely uniform manner). These tests are even more stringent than those in Table One since we are moving from examining levels to examining changes in individual support - a mechanism more directly related to the theory set out in Section Two. Each table follows the same pattern. Models One through Four examine the level of Social Security preferences in 2004 as a function of changes in the core independent variables, with Models Two through Four including the level of preferences in 2000, Model Three including regional dummies, and Model Four including information about regional price changes (and thus distinguishing between high and low appreciation regions for renters and homeowners alike). Models Five through Eight repeat the same exercise but with the change in preferences between 2000 and 2004 as the dependent variable.

Across all specifications I find a negative effect of estimated house price appreciation between 2000 and 2004 on preferences over Social Security spending, significant at, at least, the ten percent level. To provide an indication of the substantive magnitude of these effects, consider that for Model 1 of Table One, a citizen who experienced zero house price appreciation between 
2000 and 2004 would have a $2.1 \%$ chance of desiring less Social Security spending, a 30.6\% chance of desiring steady funding, and a $67.3 \%$ chance of desiring higher funding. By contrast, a citizen who experienced an estimated thirty percent increase in the real value of their home across four years (around the $70^{\text {th }}$ percentile) would have a $4.1 \%$ chance of desiring less Social Security spending, a $39.7 \%$ chance of desiring steady funding, and a $56.2 \%$ chance of desiring more funding. That is tantamount to an over ten percent point drop in the support for increasing funding. Similarly, if we examine the change dependent variable, using Model 5, we find that citizens who experienced a thirty percent house price appreciation were twice as likely (ten percent versus five percent) to desire less spending in 2004 than they did in 2000 and half as likely (four percent versus eight percent) to desire more spending than were respondents with no house price appreciation. Given that stability of preferences is extremely common (around 85 percent of the sample) these predicted effects of house price appreciation are quite dramatic.

To check on the generalizability of these findings about policy preferences in the American context, I now turn to survey evidence from two European countries: the United Kingdom and Germany. These countries form a revealing pairing. The UK, like the USA, has had fairly sizable volatility in house prices since 1970 and experienced an even greater housing boom in the early 2000s. Germany by contrast actually saw declining property values during the same period but it too had periods of rising and declining prices over the previous three decades. Germany is also well-known for having particularly low homeownership rates in comparative context. The UK, furthermore, has distinct advantages over the USA in terms of data availability - on the one hand the British Social Attitudes Surveys (BSAS) provide a greater range of questions on social insurance, pensions, and redistribution than does the ANES - and on the other hand the British Household Panel Survey (BHPS), though it provides less satisfactory social policy questions than the BSAS provides data on individuals across time and, crucially, provides individual estimates of the value of their house. 
I begin with the British Social Attitudes Surveys of 2001 and 2006. I examine three questions that relate to social insurance. The first two - on pensions and unemployment benefits follow the same rubric. Respondents are asked whether the government should spend more or less on each of these policy items. ${ }^{\text {ii }}$ In terms of redistribution, the question in both surveys is simply whether the government should redistribute income from rich to poor. Iversen and Soskice (2001) argue such redistribution is tantamount to social insurance, at least from a 'veil of ignorance' perspective. Since I lack data on how long respondents have owned their property, I estimate individual house price appreciation by examining the five year percentage increase in house prices in the region a given homeowner lives in. Thus, I am essentially recreating the 'sociotropic' measure from the NES analysis, albeit with only eleven regions. Given this limit in the number of regions, examining two surveys is helpful since many British regions did not experience sharp rises in house prices until well after 2001, whereas others such as London had booms dating back to the mid 1990s.

I employ a very similar set of control variables to Table One: gender, age, income, education, retired status, partisanship, and skill specificity. Education is measured using university degree since British education has a complicated structure at the secondary level that does not correspond well to the US case. Partisanship is taken as the composite of ideological views on redistribution, government intervention, societal fairness, and big business. ${ }^{i i i}$ Since redistribution views are included in this measure, I exclude it from the analysis of the redistribution question. Finally, skill specificity is coded from the ISCO occupational codes provided in the BSAS 2001 following the specifications of Cusack, Iversen, and Rehm (2008). The BSAS 2006 lacks this information, consequently I included broad (non-ISCO) occupational dummies in these analyses as proxy controls for skill specificity. ${ }^{\text {iv }}$ Finally, for each specification I alternate between excluding and including dummies for the region. When dummies are included, the housing variable measures differences in regions between homeowners and renters, amplified 
by the size of the regional five-year change in prices. When dummies are excluded, we obtain this effect and that between homeowners across regions with different price growth.

Table Four (a) presents results for ordered probit analyses of the pensions, unemployment, and redistribution questions. Across almost all the models we find robust negative relationships between the house price appreciation variable and social insurance preferences. As an example, the effect of moving from being a renter to a homeowner in Outer London is to reduce support for increased spending on pensions by between seven and ten percent points, depending on the model, an effect comparable in magnitude to that found in the American case. A substantively similar effect is found with regard to unemployment insurance - moving from being a renter to a homeowner with high levels of house price appreciation is associated with a ten percent point increase in the probability of desiring cuts to unemployment benefits. Finally, the same move on the house price appreciation variable is associated with a ten percent point decrease in supporting greater redistribution. Generally these effects are marginally larger in the BSAS 2006 than the BSAS 2001 but the broad similarity in robustness and magnitude suggests the effect of house price appreciation on social policy preferences is quite stable.

Table Four (b) returns to the question of which kinds of individuals are most responsive to house price changes. Once more, I divide the sample by the partisanship of individuals, this time examining solely Conservative and Labour supporters in the two samples. ${ }^{\mathrm{v}}$ As in the American case, I find that the negative effects of house price appreciation on social policy preferences are much stronger and more robust in the case of Conservatives than Labour supporters. Again the negative direction of the effect is consistent across both parties but is only robust and is much larger for right-wing voters. This provides further support for the conjecture that it is right-wing parties that are most likely to cut social spending during housing booms.

In Tables Five (a) and (b) I turn to a data source that provides much better estimates of house price appreciation in Britain but at the cost of survey questions that are less directly related to social insurance. Here I use the British Household Panel Survey, which interviews over 50,000 
citizens in a panel study for which I have data from 1991, 1993, 1995, 1997, 2000, 2004, and 2006, during which period the British housing market saw first a crash and then a long rise in house prices. During these particular surveys respondents were asked questions about their housing status (did they own or rent) and if they owned to evaluate the value of their house. Using this information I create an indicator of the change in the value of their house, adjusted for consumer price inflation, from survey to survey (the surveys are almost evenly spaced and the analyses are robust to time dummies). I use both the absolute change and the log of this change (which measures percentage change). I also create indicators for changes in other control variables: homeownership, annual income, employment status, education, number of children, and for voters of the main three political parties, partisanship. ${ }^{\mathrm{vi}} \mathrm{I}$ also include variables for gender and age, and depending on the model a linear time trend or dummies for survey year.

Table Five (a) examines the closest question on the BHPS to tapping social insurance preferences - asking people whether they agree that the government should see to it that everyone looking for work can find work - that is whether the government should implement a de facto 'full employment' policy. This is not an ideal measure of support for social insurance since if the government did indeed find a job for all citizens there would be little need for such insurance. Nonetheless, since this policy addresses government support for people at risk of unemployment or low incomes it provides some perspective on broader support for social insurance. I use as the dependent variable, change from period to period in support for the prompt, using changes in the independent variables (and levels of age and gender) as explanatory variables. Since the prompt has just five values, the possible level of change is limited and I use an ordered logit model, clustering standard errors by individual respondent. Models 1, 2, 5, and 6 examine the absolute change in house valuation, whereas Models 3, 4, 7, and 8 examine the change in logged valuations. Models 1, 3, 5, and 7 use a linear time trend, whereas Models 2, 4, 6, and 8 use year dummies. Finally the first four models exclude change in partisanship and regional dummies 
whereas the final four models include these, at the loss of around forty percent of the observations.

Across all the models we see a negative effect of self-evaluated house price appreciation on support for the prompt, albeit less statistically significant when time dummies are used (which absorb most of the change in house prices and therefore greatly reduce substantive variation). The substantial effect of rather rapid house price appreciation - say fifty percent increase over three years, is to reduce support for prompt (either strongly or somewhat support) by around five percent points. This effect while robust is rather weaker than that found with the American data this could be related either to the shorter periods under analysis here - most changes being over two years - or due to measurement error in subjective evaluations biasing coefficient estimates downwards - or it may simply reflect a weaker substantive effect of housing in the UK than in the USA. Nonetheless, in a variety of rather stringent tests we see a consistently strong finding, individual house price appreciation is associated with changes in opinion towards less support for social insurance type policies.

In Table Five (b) I extend the analysis to a more diffuse dependent variable - a compound ideological index composed of the full employment plus similar questions about whether there is one rule for the rich and one for the poor, whether industries should be nationalized, whether private enterprise solves economic problems, whether strong trade unions protect employees, and whether ordinary people are sharing in the nation's wealth. Combining these into the compound index, which has thirty points along it, permits the use of linear models and hence random effects to account for variance across the individual respondents (the panels). It also permits the inclusion of a lagged dependent variable, inappropriate in the earlier ordered probit models. Accordingly, to examine the effects of both changes and levels in house prices and the other independent variables, I employ an error correction model with the respondent's level on the ideological index as the dependent variable. I exclude the partisanship variable since overall ideology and partisanship are very closely associated but results remain similar. 
The results in Table Five (b) indicate that both changes in house prices and their level have strong negative effects on the compound ideological index and hence are associated with more right-wing ideological views. The long-run effects, once the lagged dependent variable are taken into account are quite substantial. For example, a doubling in house prices would be associated with a long decrease on two-thirds of a within-person standard deviation in ideological preferences. Thus, as with the social insurance question, it appears house prices are important predictors of social policy views in a more general setting.

I conclude the analysis of housing and social policy preferences by turning to the case of Germany. Germany, unfortunately, does not have historical data on housing prices at the Bundesland level, hence I use national house price data and examine changes in social policy preferences over the period 1988 to 2004 . I alter the specification of the model somewhat given the absence of regional data and use a dummy variable for home ownership and the interaction of this dummy with the five-year national real house price change. In Germany, house price changes are sometimes positive and sometimes negative, given that unlike the USA and the UK in the early 2000s, Germany had both housing declines and rises between 1988 and 2004. In fact the five year house price change has a mean of $-2.6 \%$.

I use three questions on social policy preferences as dependent variables. These questions do not match precisely those used in the previous two samples but there is some overlap. The first question asks whether "social benefits" should be cut or extended, referring to general social insurance policies. The second question asks whether the government should "secure the income" of all citizens in times of hardship. This question is related to social insurance motivations, albeit more to unemployment insurance than to pensions. Finally, the third question asks whether social differences are just. There is some correspondence here to the redistribution question in the BSAS, though here respondents are not asked whether the government should reduce the gap between rich and poor, simply whether that gap is fair. The three questions are available for different years in the ALLBUS survey: the social benefits question for 1994, 2000, and 2004; the 
income security question for 1991, 1994, 2000, and 2004; and the social differences question for 1988, 1991, 1994, 1998, 2000, and 2004. Thus, the latter questions reflect greater variation in house price changes than does the former. For each question I use two specifications, one with dummies for Bundesland and a skill specificity variable, and one without. All models contain dummies for the year of the survey and robust standard errors clustered by Bundesland. The skill specificity variable is calculated from ISCO codes, however these are only available for a subset of respondents (around one third). The models are presented in Table Six.

Across all the models homeownership itself has a powerful negative effect on support for social insurance policies and a positive effect on finding the gap between rich and poor to be just. Furthermore, in five of the six models, house price increases robustly accentuate the homeownership effect - and their effect is always in the same direction as the coefficient on homeownership. This is somewhat surprising since many of the years under analysis house prices are declining, which would mean that house price coefficient is negative - in such cases the effect of homeownership on opposing social insurance is thus weakened. Whereas a German homeowner is eight percent more likely than a renter to want to cut social benefits when house prices have risen ten percent, when house prices have declined by the same amount this effect more than halves and is no longer robust. This indicates that declining prices also affect the behavior of homeowners in terms of their social policy preferences - a finding with interesting implications for voters during the current housing downturn.

In sum, the analysis of the effects of homeownership and house prices on individual social policy preferences shows a powerful negative relationship that previous studies of preferences have not uncovered. The effect is one that runs near-orthogonally to traditional factors of interest like income, education, and skill specificity. The analysis shows that measures of individual wealth may, then, be as important as individual labor market status in shaping opinions about the role of government and the welfare state. However, we are still left with the 
question as to whether these preferences matter in any substantive sense - do political parties respond to the shifting views of voters?

\section{Housing Prices and Policy Outcomes at the Macro Level}

In this section I move from examining how house prices affect micro-preferences over social policies to analyzing whether house price fluctuations actually alter policy outcomes. In particular, I investigate whether the same pattern of right-wing voters being most strongly affected by house prices manifests itself at the national level through the actions of right-wing parties. The findings in this section strongly support these conjectures. Even controlling for changes in standard macroeconomic factors including national income, price inflation, unemployment, and interest rates we see powerful effects of house prices on patterns of government spending. In short, under right-wing government, the housing effect on spending is stronger. When house prices are rising, right-wing governments appear to cut spending further and faster. This finding jibes closely with the expectations I laid out in the previous section. Homeowners experience a rise in the price of their most important asset during housing booms. This leads to a lower demand for publicly provided social insurance, as houses become seen as nest eggs. Parties that disproportionately represent homeowners - those of the right - respond to their constituents' preferences by paring back social security spending. I explore this political effect of the housing cycle using cross-sectional time-series data for eighteen countries dating from 1975 to 2001 .

The key independent variable is the five-year percentage change in real house prices (i.e. inflation-adjusted), taken from the Bank of International Settlements' house price data for eighteen countries from 1970 to 2001. This housing data provides a country-specific level of house prices relative to 1970 - note this implies that house price levels cannot be usefully compared cross-sectionally, though changes can, hence my use of the five-year percentage change. ${ }^{\text {vii }}$ The mean of this variable is $12.8 \%$ (i.e. a compounded annual rate of around $2.5 \%$ ), its 
standard deviation is $25.6 \%$ and its minimum and maximum values are, respectively, $-45.8 \%$ and $118.3 \%$.

I include as controls, a set of macroeconomic variables that come from the Penn World Tables (PWT), the World Development Indicators (WDI), and the OECD. These include Gross Domestic Product (measured in $\$ 100 \mathrm{bn}$ ), the annual growth rate of GDP, both from the PWT, the $\log$ of population, the real interest rate and consumer price inflation from the WDI, and the unemployment rate from the OECD. ${ }^{\text {viii }}$ I also add two further important determinants of social spending: trade openness (Garrett, 1998; Rodrik, 2000) and the proportion of citizens over sixtyfive years of age (both from the WDI). For government partisanship I use Cusack and Engelhardt's cabinet 'center of gravity' index, which produces a measure of cabinet ideology that is a weighted average of the ideology of parties in the governing coalition (Cusack and Engelhardt, 2002). I use their 'composite ideology' index, which is based on 23 expert ratings and is also used in Iversen and Soskice (2006). This variable ranges (theoretically) between -100 and 100, with right-wing parties having higher scores, and has a mean of 3.65 , and a standard deviation of 24.15. ${ }^{\text {ix }}$ I also employ an interactive variable that is the product of cabinet ideology and the five year percentage change in house prices. It is this variable I expect to be most critical - social insurance spending should be reduced by the combination of right-wing government and house price increases.

For the dependent variables, I examine social spending policies from the OECD Social Spending dataset from 1980 to 2001, as well as OECD data on social transfers as compiled by Armingeon et al (2010). The variables taken from the OECD Social Spending dataset are total social spending as a percentage of GDP, spending on old age pensions as a percentage of GDP, and spending on unemployment benefits as a percentage of GDP. The total social spending measure includes not only pensions and unemployment but also survivors' benefits, incapacity benefits, health spending, family spending, active labor market programs, and public housing. The social transfers measure from Armingeon et al (2010) is defined as "social assistance grants 
and welfare benefits paid by general government" and has greater availability, dating back to the 1970 s and is correlated at 0.81 with the OECD total social spending variable.

Tables Seven (a) through Seven (d) through test the propositions developed above using a variety of statistical techniques on a dataset of eighteen states from 1975 to 2001, with between 280 and 396 observations across the various models. Table Seven (a) examines total social spending, Table Seven (b) looks at old age pensions spending, Table Seven (c) examines spending on unemployment benefits, and Table Seven (d) examines social security transfers. Each table contains a comparable series of statistical estimations. Model 1 is a country fixed effects analysis with a stripped down array of macroeconomic controls. Model 2 adds a further series of controls reducing the dataset somewhat in size: inflation, real interest rate, trade openness, and proportion of population over 65. Model 3 and Model 4 repeat that specification but with, respectively, an AR1 error term and a lagged dependent variable. All the fixed effects models use country-clustered standard errors. Finally Models 5 and 6 remove the country fixed effects and are pooled analyses with AR1 error terms, lagged dependent variables, and, respectively, heteroskedasticity adjusted and panel corrected standard errors. All Models except Model 6, which uses a time trend, contain year dummies.

The main finding jumping out of these tables is that the interactive variable of cabinet partisanship and house prices is negative and robust across almost all of the models. Except for unemployment spending, where the results are more mixed, the effects of house prices conditional on right-wing partisanship are to robustly decrease social spending, particularly pensions. For total spending this effect is robust at the one percent level in all but one model, for pensions in all but two models, and for social transfers at the five percent level in all but one model. For unemployment spending, the situation is mixed, only the latter three models are significant at conventional levels. Broadly, the implication is that the impact of house prices, controlling for other aspects of the business cycle and other determinants of government spending, is filtered through partisan control of government. When right-wing governments 
capture office and house prices have been appreciating we see a strong negative impact on social spending and transfers and in terms of old age pensions (with some mixed evidence on unemployment spending). Conversely, when left-wing parties are in power during periods of house price appreciation there is no distinguishable effect on social spending. Splitting the sample into left and right wing parties we do indeed find that the negative effect of house price appreciation on social spending only occurs under the latter. ${ }^{\mathrm{x}}$

This pattern can be seen in Figures One (a) and One (b), which show estimates drawn from Model A of each Tables Seven (a) and Seven (b) of the marginal effect of real house prices increasing by fifty percent (as they did in many European countries including the UK, Belgium, and Denmark during 2001-2006) on, respectively, social spending and pensions spending. ${ }^{x i}$ The figures can be interpreted as showing the estimated effect - with ninety-five percent confidence intervals - of this increase in house prices for a given level of partisanship, where negative fifty implies a fifty-point swing to the left and positive fifty implies a fifty-point swing to the right. ${ }^{\text {ii }}$ Three patterns are clearest. Firstly, when partisanship moves to the left (towards minus fifty on the $\mathrm{x}$-axis) there is little evidence of house price increases affecting either social spending (Figure One (a), except at the extreme left) or pensions spending (Figure One (b), throughout the whole range of leftward shifts in government). Secondly, when cabinet partisanship moves to the right there is a robust negative effect of house price increases on both pensions and social spending more broadly. That is, house price booms lead to decreases in social spending when right-wing parties are in power. At the extreme, a fifty point swing to the right in partisanship combined with a fifty-percent increase in house prices is associated with a reduction of social spending of just over one percent point of GDP and half a percent point of GDP in the amount of spending on pensions. These figures amount to half a within-country standard deviation in both total and pensions spending - sizable effects with substantial political implications. The final point worth noting is that even with a 'moderate' government (one with the country's mean level of 
partisanship), house price increases are associated with declines in both social and pensions spending.

I conclude this section by examining whether the aggregate level of homeownership has any impact on the findings above. Here I rely on data collected by Atterhog (2005) on home ownership rates from 1960 to 2003 across fifteen of the countries in the dataset. ${ }^{\text {xiii }}$ I examine whether the effects on social spending of house price increases conditional on partisanship, as found in the previous tables, are stronger in those countries with higher rates of homeownership. ${ }^{\text {xiv }}$ Table Eight splits countries into two groups: those with average levels of homeownership across the time period lower than the overall median and those at the median or above. I examine each of the four spending variables from Table Seven and use the same specification as Model 4. Across total spending, pensions spending, and unemployment spending the coefficient on the interactive variable is larger in magnitude and statistically far more robust for the groups of countries with higher homeownership rates than for those with lower rates. ${ }^{\mathrm{xv}}$ For social transfers the coefficient is actually slightly smaller for the high homeownership group but is robust at the ten percent level, whereas that for the low homeownership group is not robust. Homeownership itself is almost always negatively signed but is rarely a robust predictor of changes in social spending. This analysis then marks an advance on that of Conley and Gifford (2006) in showing that it is not homeownership per se that matters for public spending but rather the differential benefits homeowners obtain in terms of their wealth when house prices are rising. These effects will be more pronounced where homeownership is more widespread, as a supermajority of voters, especially right-wing voters, are homeowners who stand to benefit from changes in prices.

Thus across the last few decades, OECD countries do appear to have experienced important effects of housing on the behavior of governments. This pattern has striking political implications given the increased volatility of housing prices and the general threats to government spending in an era of potential retrenchment. The effect of housing appears refracted through the 
political system. Right-wing parties have responded to the opportunity produced by an 'ownership society' to cut back spending quite dramatically. Fluctuations in asset markets have sharp consequences for the welfare state.

\section{Global Capital and the Housing Market}

I now turn to briefly situate the interplay of housing markets, partisanship, and public spending within the context of global capital flows. This relationship is particularly crucial given that the largest gains in house prices over the past few decades have occurred in those states that ran particularly large current account deficits funded by massive capital inflows that in turn massively increased the availability of cheap credit that could be used to purchase property. Schwartz (2008), among others, has developed this argument in great detail.

A recent paper by Broz (2011) relates these patterns in the distribution of global capital flows to partisan control of government and thus provides an intriguing counterpart to this paper. Broz argues that right-wing parties have been associated in recent years with large current account deficits and hence with capital inflows in order to balance national payments. A simple extension of this argument would be to tie this newfound availability of international financing to demand for national assets, in particular housing. This connection might be apparent in two ways. Firstly, per Broz, we should expect housing booms to happen following increases in current account deficits and therefore following shifts in partisanship to the right. This, of course, raises the interesting hypothesis that housing booms are some degree endogenous to partisanship, whereas hitherto we have presumed that it is the confluence of the independent forces of rightwing partisanship and housing booms that leads to cuts in social spending. Their confluence might not be accidental and may be a direct consequence of international financial policy.

Secondly, we might expect the interactive effect of partisanship and housing booms to be strongest in those countries which are experiencing major capital inflows and in which, hence, the supply of private assets as a hedge against labor market risk is most viable. In this sense, 
globalization facilitates cuts in the welfare state not because it is constraining, perhaps due to tax competition as in Busemeyer (2010) but because it is enabling. Global capital markets enable citizens to access capital more cheaply than before and to use it to purchase assets that substitute for social insurance, thereby creating further demand for right-wing parties to cut social policy spending.

Table Nine presents some preliminary suggestive evidence for both of these claims. Models One and Two use the five percent change in house prices variable as their dependent variable and examine five year changes in other variables of interest, including the controls from Table Seven but also the five year change in the current account as a percentage of GDP. Model Two includes a control for the level of house prices five years previous. In both models the effect of current account flows is highly significant and negative - house prices increase rather sharply when states run a current account deficit. Substantively this implies that shifting from a deficit of $3.5 \%$ to a surplus of $5 \%$ of GDP is associated with an increase in house price appreciation of fifteen percent points of five years. The effect of changes in partisanship is more muted - it is only significant at conventional levels in Model Two but here we do see the expected positive relationship between right-wing government and house prices.

Models 3 and 4 provide further insight into the relationship between partisanship, global credit, housing, and public spending. These models use the same specification as Model One in Table Seven (a) but split the sample into countries with a current account surplus and those with a deficit. It is immediately apparent that the negative interactive effect of partisanship and house prices on social spending is only significant in those countries running a current account deficit that is, those that are experiencing large capital inflows that permit high levels of house price appreciation. In current account surplus countries this connection does not exist. This finding mirrors the claims in Schwartz (2008) that the behavior of current account deficit and surplus countries during the housing boom was systemically different. Here we can see how the systemic imbalances in global capital over the past decade created opportunities for 'ownership societies' 
and for welfare retrenchment but only in those countries that consumed rather than exported. There were then 'varieties of ownership societies'.

\section{In Conclusion}

The major economic story of the last decade has been the surge and collapse of house prices worldwide, building on substantial housing volatility that began to emerge in the 1980s (Shiller, 2007). Yet political economists have had very little to say about this critical phenomenon, trapped with an analytical language that speaks to the labor market but is deaf to the effects of wealth and ownership. This article presents a novel theoretical contribution that addresses this analytical and empirical gap. Ownership matters for both the preferences of citizens about what they want from government and for the actual policymaking behavior of governments themselves. Building on a theory of assets acting as self-supplied private insurance, I argued that homeowners, especially those who have experienced high levels of house price appreciation, will desire reduced levels of spending on social insurance of various stripes, from pensions, to unemployment, to redistribution in general. Furthermore, parties representing these citizens, typically right-wing parties, respond by cutting social insurance programs during housing booms. I tested these propositions in two empirical settings. First, I examined social survey data from the USA, Britain, and Germany, finding strong evidence for the claim that homeowners with appreciating property demand less social insurance and that this pattern is amplified among right-wing voters. Second, I found that right-wing parties do appear to have cut social spending more vigorously during housing booms at the national level.

Put together, these findings suggest a powerful new approach to thinking about the interaction of the economy and the welfare state. As advanced economies have encountered both increasingly volatile asset markets and retrenchment in the welfare state (Clayton and Pontusson, 1997) this theory helps us to understand how these forces are connected. Indeed, thinking about the role of ownership enables us to address a range of theoretical and empirical anomalies in 
political economy. To give an example, a core puzzle in comparative political economy is the socalled 'Robin Hood' paradox (Iversen 2006, Lindert 2004) - redistribution from the poor to the rich happens least when it is most needed, for example when inequality is high. Ownership provides one, among many, responses to this puzzle: labor market incomes alone do not fully specify individuals' demands for social insurance and redistribution. Wealth, especially that stored in housing, may act as a countervailing but often unmeasured force. As Rajan (2010) has suggested, rising house prices may take the edge of increasing income inequality for the median voter, keeping redistributive demands at bay.

Ownership also has an intriguing international dimension. Many scholars see globalization, through trade or foreign direct investment, as increasing the risk individuals face in the labor market and hence causing them to support greater social insurance (Rodrik and Mayda, 2005; Scheve and Slaughter, 2004). Accordingly, globalization may drive increases in public spending. However, Busemeyer (2009) demonstrates that globalization and public spending have been negatively related since the 1990 s, in contrast to the positive relationship apparent in earlier data (Garrett, 1998; Rodrik, 2000). This new negative relationship might, however, not be a case of 'racing to the bottom.' In fact, it may be related to the effects of globalization on private insurance as opposed to private risk. As Herman Schwartz (2008) has noted, global credit markets underpinned a political economy of cheap credit and housing booms in Anglo-American countries in the 1990 s and 2000s. While the value of homes may in the long run have been ephemeral, during the housing boom years many citizens took advantage of globalization to feather their nest eggs. Global credit then made possible the supply of private insurance and potentially reduced support for social insurance, precisely the opposite of the story commonly told about globalization and social spending. 


\section{Bibliography}

- Ansell, Ben. 2010. From the Ballot to the Blackboard. Cambridge University Press. New York, NY.

- Armingeon, K. and Leimgruber, P. and Beyeler, M. and Menegale, S. 2010. Comparative Political Dataset I. Universitat Bern.

- Atterhog, Mikael. 2005. Importance of Government Policies for Home Ownership Rates. Working Paper. Swedish Royal Institute of Technology.

- Beck, Nathaniel and Jonathan Katz. 1995. What to do (and not to do) with time-series crosssection data. American Political Science Review. 89(3):634-647.

- Boix, Carles. 1998. Political Parties, Growth and Equality. Cambridge University Press.

- Broz, J. Lawrence. 2011. Partisan Financial Cycles. Working Paper, UC San Diego, CA.

- Busemeyer, Marius. 2009. From myth to reality: Globalisation and public spending in OECD countries revisited. European Journal of Political Research. 48(4):455-482.

- Castles, Francis. 1998. The really big trade-off: Home ownership and the welfare state in the new world and the old. Acta Politica 33:5-19.

- Clayton, Richard and Jonas Pontusson. 1997. Welfare-state retrenchment revisited: entitlement cuts, public sector restructuring, and inegalitarian trends in advanced capitalist societies. World Politics. 51(1):67-98.

- Conley, Dalton and Brian Gifford. 2006. Home Ownership, Social Insurance, and the Welfare State. Sociological Forum, 21(1).

- Cusack, Thomas and Lutz Engelhardt. 2002. The PGL file collection: File structures and procedure. Wissenschaftszentrum Berlin für Sozialforschung

- Cusack, Thomas, Torben Iversen, and Philipp Rehm, 2006. Risks at work: the demand and supply sides of government redistribution. Oxford Review of Economic Policy, 22(3).

- Esping-Andersen, Götha. 1990. The Three Worlds of Welfare Capitalism. Princeton University Press. Princeton, NJ. 
- Estevez-Abe, Margarita, Torben Iversen, and David Soskice. 2001. Social Protection and the Formation of Skills: A Reinterpretation of the Welfare State. In Peter Hall and David Soskice (eds.) Varieties of Capitalism. New York: Oxford University Press.

- Garrett, Geoffrey. 1998. Partisan Politics in the Global Economy. Cambridge University Press. New York, NY.

- Goldthorpe, John. 1968. The Affluent Worker: Industrial Attitudes and Behavior. Cambridge University Press. New York, NY.

- Hacker, Jacob. 2004. Privatizing Risk without Privatizing the Welfare State: The Hidden Politics of Social Policy Retrenchment in the United States. American Political Science Review 98(2): 243-260/

- Hacker, Jacob. 2006. The Great Risk Shift. Oxford University Press, New York, NY.

- IMF. 2008. The Changing Housing Cycle and the Implications for Monetary Policy in Economic Outlook 2008.

- Iversen, Torben. 2005. Capitalism, Welfare, and Democracy. Cambridge University Press.

- Iversen, Torben. 2006. Capitalism and Democracy, in Carles Boix and Susan Stokes (eds.), Oxford Handbook of Comparative Politics, Oxford University Press.

- Iversen, Torben, and David Soskice. 2001. An Asset Theory of Social Policy Preferences. American Political Science Review 95:875-893.

- Iversen, Torben and David Soskice. 2006. Electoral Institutions and the Politics of Coalitions: Why Some Democracies Redistribute More Than Others. American Political Science Review 100 (02):165-181.

- Kemeny, Jim. 1981. The Myth of Home Ownership. London: Routledge.

- Kingston Paul, John Thompson, and Douglas Eichar. 1984. The Politics of Home Ownership. American Politics Quarterly. 12(2):131-150

- Korpi, Walter. 1983. The Democratic Class Struggle. London: Routledge.

- Lindert, Peter. 2004. Growing Public: Volume I. Cambridge University Press, New York, NY 
- Mares, Isabella. 2003. The Politics of Social Risk: Business and Welfare State Development. Cambridge University Press. New York, NY.

- Rajan, Raghuram. 2010. Fault Lines: How Hidden Fractures Still Threaten the World Economy. Princeton University Press, Princeton, NJ.

- Rehm, Philipp. 2009. Risks and Redistribution. Comparative Political Studies. 42(7).

- Rehm, Philipp. 2011. Social Policy by Popular Demand. World Politics. 63(2).

- Rodrik, Dani. 2000. Why Do More Open Economies Have Larger Governments? Journal of Political Economy $106(5): 997-1032$.

- Rodrik, Dani and Anne-Marie Mayda. 2005. Why are some people (and countries) more protectionist than others? European Economic Review. 49(6):1393-1430.

- Samanni, Marcus, Jan Teorell, Staffan Kumlin \& Bo Rothstein. 2008. The QoG Social Policy Dataset. Version 240ct08. University of Gothenburg: The Quality of Government Institute, http://www.qog.pol.gu.se.

- Scheve, Kenneth and Matthew Slaughter. 2001. What Determines Individual Trade Policy Preferences? Journal of International Economics. 54(2):267-292.

- Scheve, Kenneth and Matthew Slaughter. 2004. Economic Insecurity and the Globalization of Production. American Journal of Political Science. 48(4):662-674.

- Schwartz, Herman, 2009. Subprime Nation. Cornell University Press, Ithaca, NY.

- Schwartz, Herman and Leonard Seabrooke. 2008. Varieties of Residential Capitalism in the International Political Economy: Old Welfare States and the New Politics of Housing. Comparative European Politics. 6(3).

- Shiller, Robert. 2007. Irrational Exuberance. Doubleday Press, New York, NY.

- Verberg, Norine. 2000. Homeownership and Politics: Testing the Political Incorporation Thesis. Canadian Journal of Sociology 25(2):169-195. 
Table One: NES 2004 Static Analysis

\begin{tabular}{|c|c|c|c|c|c|c|c|c|}
\hline & A1 & $\mathrm{A} 2$ & A3 & A4 & B1 & B2 & B3 & B4 \\
\hline State HP Ch & $\begin{array}{c}-0.208 \\
(0.046)\end{array}$ & $\begin{array}{l}-0.225 \\
(0.032)\end{array}$ & $\begin{array}{c}-0.242 \\
(0.036)\end{array}$ & $\begin{array}{c}-0.335 \\
(0.010)\end{array}$ & & & & \\
\hline State/MSA Ch & & & & & $\begin{array}{l}-0.185 \\
(0.051)\end{array}$ & $\begin{array}{c}-0.195 \\
(0.044)\end{array}$ & $\begin{array}{l}-0.226 \\
(0.073)\end{array}$ & $\begin{array}{l}-0.252 \\
(0.048)\end{array}$ \\
\hline Own House & & $\begin{array}{c}0.038 \\
(0.800)\end{array}$ & $\begin{array}{c}0.027 \\
(0.863)\end{array}$ & $\begin{array}{c}0.033 \\
(0.843)\end{array}$ & & $\begin{array}{c}0.024 \\
(0.869)\end{array}$ & $\begin{array}{l}-0.011 \\
(0.946)\end{array}$ & $\begin{array}{l}-0.001 \\
(0.996)\end{array}$ \\
\hline Party ID & $\begin{array}{c}-\mathbf{0 . 0 6 8} \\
(0.000)\end{array}$ & $\begin{array}{l}-0.068 \\
(0.000)\end{array}$ & $\begin{array}{c}-\mathbf{0 . 0 8 0} \\
(\mathbf{0 . 0 0 0 )}\end{array}$ & $\begin{array}{c}-0.075 \\
(0.000)\end{array}$ & $\begin{array}{l}-0.069 \\
(0.000)\end{array}$ & $\begin{array}{l}-\mathbf{0 . 0 6 9} \\
(\mathbf{0 . 0 0 0 )}\end{array}$ & $\begin{array}{c}\mathbf{- 0 . 0 7 7} \\
(\mathbf{0 . 0 0 0 )}\end{array}$ & $\begin{array}{l}-0.076 \\
(0.000)\end{array}$ \\
\hline Education & $\begin{array}{c}-0.132 \\
(0.000)\end{array}$ & $\begin{array}{c}-0.132 \\
(0.000)\end{array}$ & $\begin{array}{c}-0.114 \\
(0.002)\end{array}$ & $\begin{array}{c}-0.125 \\
(0.001)\end{array}$ & $\begin{array}{l}-0.132 \\
(0.000)\end{array}$ & $\begin{array}{c}-0.132 \\
(0.000)\end{array}$ & $\begin{array}{c}-0.117 \\
(0.002)\end{array}$ & $\begin{array}{l}-0.124 \\
(0.000)\end{array}$ \\
\hline HH Income & $\begin{array}{l}-0.008 \\
(0.395)\end{array}$ & $\begin{array}{l}-0.009 \\
(0.368)\end{array}$ & $\begin{array}{c}-0.017 \\
(0.119)\end{array}$ & $\begin{array}{c}-0.015 \\
(0.228)\end{array}$ & $\begin{array}{l}-0.009 \\
(0.378)\end{array}$ & $\begin{array}{l}-0.009 \\
(0.372)\end{array}$ & $\begin{array}{c}-0.017 \\
(0.168)\end{array}$ & $\begin{array}{l}-0.014 \\
(0.225)\end{array}$ \\
\hline Retired & $\begin{array}{l}-0.187 \\
(0.201)\end{array}$ & $\begin{array}{l}-0.188 \\
(0.201)\end{array}$ & $\begin{array}{c}-0.192 \\
(0.198)\end{array}$ & $\begin{array}{l}-0.222 \\
(0.142)\end{array}$ & $\begin{array}{l}-0.186 \\
(0.200)\end{array}$ & $\begin{array}{l}-0.187 \\
(0.200)\end{array}$ & $\begin{array}{c}-0.179 \\
(0.246)\end{array}$ & $\begin{array}{l}-0.223 \\
(0.137)\end{array}$ \\
\hline Self Empl. & $\begin{array}{c}-0.296 \\
(0.016)\end{array}$ & $\begin{array}{l}-0.297 \\
(0.017)\end{array}$ & $\begin{array}{c}-0.308 \\
(0.015)\end{array}$ & $\begin{array}{c}-0.300 \\
(0.022)\end{array}$ & $\begin{array}{l}-0.295 \\
(0.016)\end{array}$ & $\begin{array}{c}-0.296 \\
(0.018)\end{array}$ & $\begin{array}{c}-0.284 \\
(0.028)\end{array}$ & $\begin{array}{l}-0.299 \\
(0.020)\end{array}$ \\
\hline Unemployed & $\begin{array}{l}-0.004 \\
(0.988)\end{array}$ & $\begin{array}{l}-0.008 \\
(0.976)\end{array}$ & $\begin{array}{c}-0.009 \\
(0.976)\end{array}$ & $\begin{array}{c}0.032 \\
(0.912)\end{array}$ & $\begin{array}{l}-0.001 \\
(0.998)\end{array}$ & $\begin{array}{l}-0.003 \\
(0.991)\end{array}$ & $\begin{array}{c}-0.024 \\
(0.938)\end{array}$ & $\begin{array}{c}0.035 \\
(0.905)\end{array}$ \\
\hline Gender & $\begin{array}{c}0.196 \\
(0.027)\end{array}$ & $\begin{array}{c}0.195 \\
(0.027)\end{array}$ & $\begin{array}{c}0.191 \\
(0.032)\end{array}$ & $\begin{array}{c}0.203 \\
(0.028)\end{array}$ & $\begin{array}{c}0.193 \\
(0.026)\end{array}$ & $\begin{array}{c}0.193 \\
(0.027)\end{array}$ & $\begin{array}{c}0.190 \\
(0.038)\end{array}$ & $\begin{array}{c}0.199 \\
(0.029)\end{array}$ \\
\hline Age & $\begin{array}{c}0.002 \\
(0.483)\end{array}$ & $\begin{array}{c}0.001 \\
(0.565)\end{array}$ & $\begin{array}{c}0.000 \\
(0.965)\end{array}$ & $\begin{array}{c}0.001 \\
(0.647)\end{array}$ & $\begin{array}{c}0.001 \\
(0.542)\end{array}$ & $\begin{array}{c}0.001 \\
(0.619)\end{array}$ & $\begin{array}{c}-0.000 \\
(0.916)\end{array}$ & $\begin{array}{c}0.001 \\
(0.744)\end{array}$ \\
\hline Black & $\begin{array}{c}0.482 \\
(0.001)\end{array}$ & $\begin{array}{c}0.484 \\
(0.001)\end{array}$ & $\begin{array}{c}0.469 \\
(0.002)\end{array}$ & $\begin{array}{c}0.497 \\
(0.001)\end{array}$ & $\begin{array}{c}0.484 \\
(0.001)\end{array}$ & $\begin{array}{c}0.486 \\
(0.001)\end{array}$ & $\begin{array}{c}0.461 \\
(0.005)\end{array}$ & $\begin{array}{c}0.489 \\
(0.002)\end{array}$ \\
\hline Hispanic & $\begin{array}{l}-0.192 \\
(0.270)\end{array}$ & $\begin{array}{l}-0.190 \\
(0.272)\end{array}$ & $\begin{array}{c}-0.280 \\
(0.114)\end{array}$ & $\begin{array}{c}-0.286 \\
(0.195)\end{array}$ & $\begin{array}{l}-0.197 \\
(0.259)\end{array}$ & $\begin{array}{l}-0.196 \\
(0.260)\end{array}$ & $\begin{array}{c}-0.299 \\
(0.178)\end{array}$ & $\begin{array}{l}-0.295 \\
(0.180)\end{array}$ \\
\hline Asian & $\begin{array}{l}-0.250 \\
(0.386)\end{array}$ & $\begin{array}{l}-0.246 \\
(0.391)\end{array}$ & $\begin{array}{c}-0.256 \\
(0.399)\end{array}$ & $\begin{array}{c}-0.271 \\
(0.390)\end{array}$ & $\begin{array}{l}-0.249 \\
(0.384)\end{array}$ & $\begin{array}{l}-0.247 \\
(0.387)\end{array}$ & $\begin{array}{c}-0.283 \\
(0.370)\end{array}$ & $\begin{array}{l}-0.272 \\
(0.384)\end{array}$ \\
\hline No. of kids & $\begin{array}{c}0.053 \\
(0.314)\end{array}$ & $\begin{array}{c}0.052 \\
(0.323)\end{array}$ & $\begin{array}{c}0.031 \\
(0.626)\end{array}$ & $\begin{array}{c}0.026 \\
(0.693)\end{array}$ & $\begin{array}{c}0.054 \\
(0.300)\end{array}$ & $\begin{array}{c}0.054 \\
(0.306)\end{array}$ & $\begin{array}{c}0.026 \\
(0.704)\end{array}$ & $\begin{array}{c}0.028 \\
(0.674)\end{array}$ \\
\hline Skill Spec. & $\begin{array}{l}-0.042 \\
(0.275)\end{array}$ & $\begin{array}{l}-0.042 \\
(0.272)\end{array}$ & $\begin{array}{c}-0.036 \\
(0.339)\end{array}$ & $\begin{array}{c}-0.038 \\
(0.313)\end{array}$ & $\begin{array}{l}-0.043 \\
(0.249)\end{array}$ & $\begin{array}{c}-0.044 \\
(0.243)\end{array}$ & $\begin{array}{c}-0.038 \\
(0.312)\end{array}$ & $\begin{array}{l}-0.039 \\
(0.298)\end{array}$ \\
\hline Region Effects & $\mathrm{N}$ & $\mathrm{N}$ & STATE & MSA & $\mathrm{N}$ & $\mathrm{N}$ & ST/MSA & MSA \\
\hline 5 Yr Change & $\mathrm{N}$ & $\mathrm{N}$ & $\mathrm{N}$ & $\mathrm{Y}$ & $\mathrm{N}$ & $\mathrm{N}$ & $\mathrm{N}$ & $\mathrm{Y}$ \\
\hline$N$ & 1016 & 1016 & 1016 & 1016 & 1016 & 1016 & 1016 & 1016 \\
\hline
\end{tabular}


Table Two: Social Security Preferences and House Prices by Conservatism

\begin{tabular}{|c|c|c|}
\hline & $\begin{array}{c}(1) \\
G W B>=50\end{array}$ & $\begin{array}{c}(2) \\
G W B<50\end{array}$ \\
\hline State/MSA Ch & $\begin{array}{l}-0.307 \\
(0.031)\end{array}$ & $\begin{array}{l}-0.021 \\
(0.914)\end{array}$ \\
\hline Own House & $\begin{array}{c}0.185 \\
(0.270)\end{array}$ & $\begin{array}{l}-0.165 \\
(0.468)\end{array}$ \\
\hline Education & $\begin{array}{l}-0.207 \\
(0.000)\end{array}$ & $\begin{array}{l}-0.029 \\
(0.552)\end{array}$ \\
\hline HH Income & $\begin{array}{l}-0.012 \\
(0.369)\end{array}$ & $\begin{array}{l}-0.009 \\
(0.546)\end{array}$ \\
\hline Retired & $\begin{array}{l}-0.225 \\
(0.211)\end{array}$ & $\begin{array}{l}-0.005 \\
(0.985)\end{array}$ \\
\hline Self Empl. & $\begin{array}{l}-0.376 \\
(0.012)\end{array}$ & $\begin{array}{l}-0.203 \\
(0.311)\end{array}$ \\
\hline Unemployed & $\begin{array}{c}0.355 \\
(0.406)\end{array}$ & $\begin{array}{c}0.027 \\
(0.935)\end{array}$ \\
\hline Gender & $\begin{array}{c}0.249 \\
(0.015)\end{array}$ & $\begin{array}{c}0.187 \\
(0.252)\end{array}$ \\
\hline Age & $\begin{array}{c}0.001 \\
(0.689)\end{array}$ & $\begin{array}{c}0.000 \\
(0.938)\end{array}$ \\
\hline Black & $\begin{array}{c}0.695 \\
(0.001)\end{array}$ & $\begin{array}{c}0.503 \\
(0.021)\end{array}$ \\
\hline Hispanic & $\begin{array}{l}-0.300 \\
(0.166)\end{array}$ & $\begin{array}{c}0.070 \\
(0.811)\end{array}$ \\
\hline Asian & $\begin{array}{l}-0.324 \\
(0.368)\end{array}$ & $\begin{array}{l}-0.024 \\
(0.962)\end{array}$ \\
\hline No. of kids & $\begin{array}{c}0.012 \\
(0.796)\end{array}$ & $\begin{array}{c}0.096 \\
(0.399)\end{array}$ \\
\hline Skill Spec. & $\begin{array}{l}-0.059 \\
(0.140)\end{array}$ & $\begin{array}{l}-0.010 \\
(0.881)\end{array}$ \\
\hline$N$ & 634 & 393 \\
\hline
\end{tabular}

$p$-values in parentheses 
Table Three (a): Panel Analysis NES 2000 / 2004 State Measure of House Prices

\begin{tabular}{|c|c|c|c|c|c|c|c|c|}
\hline & $\begin{array}{c}\mathrm{A} 1 \\
\text { Soc Sec } \\
2004\end{array}$ & $\begin{array}{c}\text { A2 } \\
\text { Soc Sec } \\
2004 \\
\end{array}$ & $\begin{array}{c}\text { A3 } \\
\text { Soc Sec } \\
2004 \\
\end{array}$ & $\begin{array}{c}\text { A4 } \\
\text { Soc Sec } \\
2004 \\
\end{array}$ & $\begin{array}{c}\mathrm{B} 1 \\
\Delta \mathrm{Soc} \\
\mathrm{Sec} \\
\end{array}$ & $\begin{array}{c}\mathrm{B} 2 \\
\Delta \mathrm{Soc} \\
\mathrm{Sec} \\
\end{array}$ & $\begin{array}{c}\text { B3 } \\
\Delta \text { Soc } \\
\text { Sec } \\
\end{array}$ & $\begin{array}{c}\text { B4 } \\
\Delta \text { Soc } \\
\text { Sec } \\
\end{array}$ \\
\hline Soc Sec 2000 & & $\begin{array}{c}0.712 \\
(0.000)\end{array}$ & $\begin{array}{c}0.872 \\
(0.000)\end{array}$ & $\begin{array}{c}0.712 \\
(0.000)\end{array}$ & & $\begin{array}{c}-1.931 \\
(0.000)\end{array}$ & $\begin{array}{c}-2.017 \\
(0.000)\end{array}$ & $\begin{array}{l}-1.931 \\
(0.000)\end{array}$ \\
\hline$\Delta$ Income & $\begin{array}{c}-0.057 \\
(0.310)\end{array}$ & $\begin{array}{l}-0.094 \\
(0.157)\end{array}$ & $\begin{array}{l}-0.116 \\
(0.093)\end{array}$ & $\begin{array}{c}-0.094 \\
(0.154)\end{array}$ & $\begin{array}{l}-0.123 \\
(0.082)\end{array}$ & $\begin{array}{c}-0.094 \\
(0.158)\end{array}$ & $\begin{array}{c}-0.116 \\
(0.103)\end{array}$ & $\begin{array}{l}-0.094 \\
(0.155)\end{array}$ \\
\hline$\Delta$ House Value & $\begin{array}{c}-0.971 \\
(0.002)\end{array}$ & $\begin{array}{c}-1.048 \\
(0.001)\end{array}$ & $\begin{array}{l}-1.116 \\
(0.077)\end{array}$ & $\begin{array}{l}-1.042 \\
(0.097)\end{array}$ & $\begin{array}{c}-0.718 \\
(0.030)\end{array}$ & $\begin{array}{l}-1.131 \\
(0.001)\end{array}$ & $\begin{array}{l}-1.164 \\
(0.078)\end{array}$ & $\begin{array}{l}-1.141 \\
(0.068)\end{array}$ \\
\hline$\Delta$ Own House & $\begin{array}{c}0.231 \\
(0.192)\end{array}$ & $\begin{array}{c}0.152 \\
(0.379)\end{array}$ & $\begin{array}{c}0.083 \\
(0.666)\end{array}$ & $\begin{array}{c}0.153 \\
(0.404)\end{array}$ & $\begin{array}{l}-0.021 \\
(0.898)\end{array}$ & $\begin{array}{c}0.108 \\
(0.499)\end{array}$ & $\begin{array}{c}0.038 \\
(0.830)\end{array}$ & $\begin{array}{c}0.107 \\
(0.526)\end{array}$ \\
\hline$\Delta$ Party ID & $\begin{array}{c}0.020 \\
(0.636)\end{array}$ & $\begin{array}{c}0.033 \\
(0.537)\end{array}$ & $\begin{array}{c}0.058 \\
(0.297)\end{array}$ & $\begin{array}{c}0.033 \\
(0.537)\end{array}$ & $\begin{array}{c}0.035 \\
(0.491)\end{array}$ & $\begin{array}{c}0.035 \\
(0.496)\end{array}$ & $\begin{array}{c}0.051 \\
(0.348)\end{array}$ & $\begin{array}{c}0.035 \\
(0.495)\end{array}$ \\
\hline$\Delta$ Retired & $\begin{array}{c}0.216 \\
(0.217)\end{array}$ & $\begin{array}{c}0.300 \\
(0.050)\end{array}$ & $\begin{array}{c}0.317 \\
(\mathbf{0 . 0 2 9})\end{array}$ & $\begin{array}{c}0.300 \\
(0.050)\end{array}$ & $\begin{array}{c}0.258 \\
(0.106)\end{array}$ & $\begin{array}{c}0.249 \\
(0.066)\end{array}$ & $\begin{array}{c}0.284 \\
(0.031)\end{array}$ & $\begin{array}{c}0.249 \\
(0.066)\end{array}$ \\
\hline Age & $\begin{array}{c}0.006 \\
(0.138)\end{array}$ & $\begin{array}{c}0.003 \\
(0.516)\end{array}$ & $\begin{array}{c}0.007 \\
(0.150)\end{array}$ & $\begin{array}{c}0.003 \\
(0.519)\end{array}$ & $\begin{array}{c}0.001 \\
(0.909)\end{array}$ & $\begin{array}{c}0.004 \\
(0.390)\end{array}$ & $\begin{array}{c}0.008 \\
(0.125)\end{array}$ & $\begin{array}{c}0.004 \\
(0.391)\end{array}$ \\
\hline Gender & $\begin{array}{c}0.241 \\
(0.035)\end{array}$ & $\begin{array}{c}0.114 \\
(0.364)\end{array}$ & $\begin{array}{c}0.136 \\
(0.361)\end{array}$ & $\begin{array}{c}0.114 \\
(0.364)\end{array}$ & $\begin{array}{l}-0.114 \\
(0.274)\end{array}$ & $\begin{array}{c}0.139 \\
(0.226)\end{array}$ & $\begin{array}{c}0.167 \\
(0.226)\end{array}$ & $\begin{array}{c}0.139 \\
(0.224)\end{array}$ \\
\hline Black & $\begin{array}{c}0.402 \\
(0.260)\end{array}$ & $\begin{array}{c}0.138 \\
(0.700)\end{array}$ & $\begin{array}{c}0.202 \\
(0.576)\end{array}$ & $\begin{array}{c}0.138 \\
(0.701)\end{array}$ & $\begin{array}{l}-0.333 \\
(0.106)\end{array}$ & $\begin{array}{c}0.099 \\
(0.747)\end{array}$ & $\begin{array}{c}0.155 \\
(0.578)\end{array}$ & $\begin{array}{c}0.099 \\
(0.749)\end{array}$ \\
\hline Hispanic & $\begin{array}{c}0.374 \\
(0.416)\end{array}$ & $\begin{array}{c}0.170 \\
(0.676)\end{array}$ & $\begin{array}{c}0.420 \\
(0.296)\end{array}$ & $\begin{array}{c}0.171 \\
(0.656)\end{array}$ & $\begin{array}{l}-0.289 \\
(0.163)\end{array}$ & $\begin{array}{c}0.032 \\
(0.933)\end{array}$ & $\begin{array}{c}0.256 \\
(0.505)\end{array}$ & $\begin{array}{c}0.031 \\
(0.933)\end{array}$ \\
\hline Asian & $\begin{array}{c}-0.849 \\
(0.000)\end{array}$ & $\begin{array}{c}-0.972 \\
(0.000)\end{array}$ & $\begin{array}{l}-1.009 \\
(0.000)\end{array}$ & $\begin{array}{c}-0.970 \\
(0.000)\end{array}$ & $\begin{array}{l}-0.843 \\
(0.005)\end{array}$ & $\begin{array}{c}-1.025 \\
(0.000)\end{array}$ & $\begin{array}{c}-\mathbf{1 . 0 5 7} \\
(\mathbf{0 . 0 0 0 )}\end{array}$ & $\begin{array}{l}-1.027 \\
(0.000)\end{array}$ \\
\hline State Dummies & $\mathrm{N}$ & $\mathrm{N}$ & $\mathrm{Y}$ & $\mathrm{N}$ & $\mathrm{N}$ & $\mathrm{N}$ & $\mathrm{Y}$ & $\mathrm{N}$ \\
\hline Price Level & $\mathrm{N}$ & $\mathrm{N}$ & $\mathrm{N}$ & $\mathrm{Y}$ & $\mathrm{N}$ & $\mathrm{N}$ & $\mathrm{N}$ & $\mathrm{Y}$ \\
\hline$N$ & 634 & 619 & 619 & 619 & 619 & 619 & 619 & 619 \\
\hline
\end{tabular}


Table Three(b): Panel Analysis NES 2000-2004 State/MSA Measure of House Prices

\begin{tabular}{|c|c|c|c|c|c|c|c|c|}
\hline & $\begin{array}{c}\text { A1 } \\
\text { Soc Sec } \\
2004\end{array}$ & $\begin{array}{c}\text { A2 } \\
\text { Soc Sec } \\
2004\end{array}$ & $\begin{array}{c}\text { A3 } \\
\text { Soc Sec } \\
2004 \\
\end{array}$ & $\begin{array}{c}\text { A4 } \\
\text { Soc Sec } \\
2004\end{array}$ & $\begin{array}{c}\mathrm{B} 1 \\
\Delta \mathrm{Soc} \\
\mathrm{Sec} \\
\end{array}$ & $\begin{array}{c}\mathrm{B} 2 \\
\Delta \mathrm{Soc} \\
\mathrm{Sec} \\
\end{array}$ & $\begin{array}{c}\text { B3 } \\
\Delta \text { Soc } \\
\text { Sec } \\
\end{array}$ & $\begin{array}{c}\text { B4 } \\
\Delta \text { Soc } \\
\text { Sec } \\
\end{array}$ \\
\hline Soc Sec 2000 & & $\begin{array}{c}0.742 \\
(0.000)\end{array}$ & $\begin{array}{c}0.862 \\
(0.000)\end{array}$ & $\begin{array}{c}0.740 \\
(0.000)\end{array}$ & & $\begin{array}{l}-1.887 \\
(0.000)\end{array}$ & $\begin{array}{l}-2.256 \\
(0.000)\end{array}$ & $\begin{array}{l}-1.894 \\
(0.000)\end{array}$ \\
\hline$\Delta$ Income & $\begin{array}{c}-0.051 \\
(0.378)\end{array}$ & $\begin{array}{c}-0.089 \\
(0.205)\end{array}$ & $\begin{array}{c}-0.088 \\
(0.271)\end{array}$ & $\begin{array}{c}-0.088 \\
(0.210)\end{array}$ & $\begin{array}{l}-0.115 \\
(0.130)\end{array}$ & $\begin{array}{l}-0.087 \\
(0.215)\end{array}$ & $\begin{array}{l}-0.083 \\
(0.316)\end{array}$ & $\begin{array}{l}-0.086 \\
(0.222)\end{array}$ \\
\hline$\Delta$ House Value & $\begin{array}{c}-0.731 \\
(0.042)\end{array}$ & $\begin{array}{c}-0.914 \\
(0.009)\end{array}$ & $\begin{array}{l}-1.438 \\
(0.090)\end{array}$ & $\begin{array}{c}-1.173 \\
(0.100)\end{array}$ & $\begin{array}{c}-0.790 \\
(0.015)\end{array}$ & $\begin{array}{c}-0.939 \\
(0.013)\end{array}$ & $\begin{array}{l}-1.413 \\
(0.091)\end{array}$ & $\begin{array}{l}-1.236 \\
(0.071)\end{array}$ \\
\hline$\Delta$ Own House & $\begin{array}{c}0.237 \\
(0.178)\end{array}$ & $\begin{array}{c}0.158 \\
(0.358)\end{array}$ & $\begin{array}{c}-0.073 \\
(0.741)\end{array}$ & $\begin{array}{c}0.148 \\
(0.409)\end{array}$ & $\begin{array}{c}-0.014 \\
(0.930)\end{array}$ & $\begin{array}{c}0.113 \\
(0.477)\end{array}$ & $\begin{array}{c}-0.074 \\
(0.708)\end{array}$ & $\begin{array}{c}0.101 \\
(0.543)\end{array}$ \\
\hline$\Delta$ Party ID & $\begin{array}{c}0.023 \\
(0.595)\end{array}$ & $\begin{array}{c}0.039 \\
(0.477)\end{array}$ & $\begin{array}{c}0.079 \\
(0.230)\end{array}$ & $\begin{array}{c}0.039 \\
(0.481)\end{array}$ & $\begin{array}{c}0.043 \\
(0.409)\end{array}$ & $\begin{array}{c}0.040 \\
(0.443)\end{array}$ & $\begin{array}{c}0.067 \\
(0.285)\end{array}$ & $\begin{array}{c}0.040 \\
(0.450)\end{array}$ \\
\hline$\Delta$ Retired & $\begin{array}{c}0.214 \\
(0.239)\end{array}$ & $\begin{array}{c}0.301 \\
(0.056)\end{array}$ & $\begin{array}{c}0.349 \\
(0.120)\end{array}$ & $\begin{array}{c}0.305 \\
(0.054)\end{array}$ & $\begin{array}{c}0.266 \\
(0.102)\end{array}$ & $\begin{array}{c}0.247 \\
(0.076)\end{array}$ & $\begin{array}{c}0.322 \\
(0.098)\end{array}$ & $\begin{array}{c}0.252 \\
(0.073)\end{array}$ \\
\hline Age & $\begin{array}{c}0.006 \\
(0.144)\end{array}$ & $\begin{array}{c}0.004 \\
(0.479)\end{array}$ & $\begin{array}{c}0.008 \\
(0.133)\end{array}$ & $\begin{array}{c}0.004 \\
(0.472)\end{array}$ & $\begin{array}{c}0.002 \\
(0.758)\end{array}$ & $\begin{array}{c}0.004 \\
(0.364)\end{array}$ & $\begin{array}{c}0.008 \\
(0.102)\end{array}$ & $\begin{array}{c}0.004 \\
(0.350)\end{array}$ \\
\hline Gender & $\begin{array}{c}0.244 \\
(0.034)\end{array}$ & $\begin{array}{c}0.114 \\
(0.372)\end{array}$ & $\begin{array}{c}0.136 \\
(0.455)\end{array}$ & $\begin{array}{c}0.118 \\
(0.361)\end{array}$ & $\begin{array}{l}-0.109 \\
(0.306)\end{array}$ & $\begin{array}{c}0.139 \\
(0.232)\end{array}$ & $\begin{array}{c}0.186 \\
(0.270)\end{array}$ & $\begin{array}{c}0.145 \\
(0.216)\end{array}$ \\
\hline Black & $\begin{array}{c}0.407 \\
(0.253)\end{array}$ & $\begin{array}{c}0.125 \\
(0.726)\end{array}$ & $\begin{array}{c}0.117 \\
(0.770)\end{array}$ & $\begin{array}{c}0.121 \\
(0.734)\end{array}$ & $\begin{array}{c}-0.341 \\
(0.110)\end{array}$ & $\begin{array}{c}0.093 \\
(0.763)\end{array}$ & $\begin{array}{c}0.078 \\
(0.805)\end{array}$ & $\begin{array}{c}0.088 \\
(0.776)\end{array}$ \\
\hline Hispanic & $\begin{array}{c}0.392 \\
(0.391)\end{array}$ & $\begin{array}{c}0.176 \\
(0.657)\end{array}$ & $\begin{array}{c}0.558 \\
(0.225)\end{array}$ & $\begin{array}{c}0.141 \\
(0.702)\end{array}$ & $\begin{array}{l}-0.289 \\
(0.155)\end{array}$ & $\begin{array}{c}0.043 \\
(0.909)\end{array}$ & $\begin{array}{c}0.401 \\
(0.367)\end{array}$ & $\begin{array}{c}0.001 \\
(0.998)\end{array}$ \\
\hline Asian & $\begin{array}{c}-0.960 \\
(0.000)\end{array}$ & $\begin{array}{c}-1.315 \\
(0.000)\end{array}$ & $\begin{array}{c}-1.448 \\
(0.000)\end{array}$ & $\begin{array}{c}-1.374 \\
(0.000)\end{array}$ & $\begin{array}{c}-1.462 \\
(0.000)\end{array}$ & $\begin{array}{l}-1.275 \\
(0.000)\end{array}$ & $\begin{array}{l}-1.308 \\
(0.000)\end{array}$ & $\begin{array}{l}-1.349 \\
(0.000)\end{array}$ \\
\hline $\begin{array}{l}\text { State/MSA } \\
\text { Dummies }\end{array}$ & $\mathrm{N}$ & $\mathrm{N}$ & $\mathrm{Y}$ & $\mathrm{N}$ & $\mathrm{N}$ & $\mathrm{N}$ & $\mathrm{Y}$ & $\mathrm{N}$ \\
\hline Price Level & $\mathrm{N}$ & $\mathrm{N}$ & $\mathrm{N}$ & $\mathrm{Y}$ & $\mathrm{N}$ & $\mathrm{N}$ & $\mathrm{N}$ & $\mathrm{Y}$ \\
\hline$N$ & 634 & 619 & 619 & 619 & 619 & 619 & 619 & 619 \\
\hline$N$ with MSA & 254 & 249 & 249 & 249 & 249 & 249 & 249 & 249 \\
\hline
\end{tabular}

$p$ values in parentheses. $\mathrm{p}<0.1$ in italics, $\mathrm{p}<0.05$ in bold. Standard errors clustered by state. 
Table Four (a): British Social Attitudes Survey 2001 and 2006

\begin{tabular}{|c|c|c|c|c|c|c|}
\hline BSAS 2001 & $\begin{array}{c}(1) \\
\text { PENSIONS }\end{array}$ & $\begin{array}{c}(2) \\
\text { PENSIONS }\end{array}$ & $\begin{array}{c}(3) \\
\text { UNEMP }\end{array}$ & $\begin{array}{c}(4) \\
\text { UNEMP }\end{array}$ & $\begin{array}{c}(5) \\
\text { REDIST }\end{array}$ & $\begin{array}{c}(6) \\
\text { REDIST }\end{array}$ \\
\hline HomeOwn* \% 5yr & $\begin{array}{c}-0.244 * * * \\
(0.089)\end{array}$ & $\begin{array}{l}-0.188^{*} \\
(0.103)\end{array}$ & $\begin{array}{c}-0.329 * * \\
(0.167)\end{array}$ & $\begin{array}{c}-0.428 * * \\
(0.206)\end{array}$ & $\begin{array}{l}-0.147 \\
(0.156)\end{array}$ & $\begin{array}{l}-0.304 * \\
(0.167)\end{array}$ \\
\hline Gender & $\begin{array}{c}0.099 * * * \\
(0.034)\end{array}$ & $\begin{array}{c}0.100 * * * \\
(0.035)\end{array}$ & $\begin{array}{l}0.103^{*} \\
(0.055)\end{array}$ & $\begin{array}{l}0.105^{*} \\
(0.056)\end{array}$ & $\begin{array}{l}-0.091 \\
(0.057)\end{array}$ & $\begin{array}{l}-0.084 \\
(0.056)\end{array}$ \\
\hline Age & $\begin{array}{c}0.010 * * * \\
(0.002)\end{array}$ & $\begin{array}{c}0.010 * * * \\
(0.002)\end{array}$ & $\begin{array}{l}-0.000 \\
(0.002)\end{array}$ & $\begin{array}{l}-0.000 \\
(0.002)\end{array}$ & $\begin{array}{l}0.003^{*} \\
(0.002)\end{array}$ & $\begin{array}{l}0.004 * \\
(0.002)\end{array}$ \\
\hline Income & $\begin{array}{l}-0.044^{*} \\
(0.024)\end{array}$ & $\begin{array}{l}-0.046^{*} \\
(0.025)\end{array}$ & $\begin{array}{c}-0.064 * * \\
(0.025)\end{array}$ & $\begin{array}{c}-0.060 * * \\
(0.025)\end{array}$ & $\begin{array}{c}-0.159 * * * \\
(0.023)\end{array}$ & $\begin{array}{c}-0.153 * * * \\
(0.024)\end{array}$ \\
\hline Degree & $\begin{array}{c}-0.137 * * \\
(0.066)\end{array}$ & $\begin{array}{c}-0.136^{* *} \\
(0.067)\end{array}$ & $\begin{array}{c}0.253 * * * \\
(0.039)\end{array}$ & $\begin{array}{c}0.241 * * * \\
(0.035)\end{array}$ & $\begin{array}{c}0.448 * * * \\
(0.069)\end{array}$ & $\begin{array}{c}0.440 * * * \\
(0.066)\end{array}$ \\
\hline Retired & $\begin{array}{c}0.046 \\
(0.088)\end{array}$ & $\begin{array}{c}0.046 \\
(0.089)\end{array}$ & $\begin{array}{c}0.066 \\
(0.047)\end{array}$ & $\begin{array}{c}0.066 \\
(0.047)\end{array}$ & $\begin{array}{l}-0.066 \\
(0.086)\end{array}$ & $\begin{array}{l}-0.072 \\
(0.088)\end{array}$ \\
\hline Skill Specificity & $\begin{array}{c}0.058 * * * \\
(0.017)\end{array}$ & $\begin{array}{c}0.054 * * * \\
(0.018)\end{array}$ & $\begin{array}{l}-0.000 \\
(0.037)\end{array}$ & $\begin{array}{c}0.003 \\
(0.037)\end{array}$ & $\begin{array}{c}0.134 * * * \\
(0.043)\end{array}$ & $\begin{array}{c}0.133 * * * \\
(0.042)\end{array}$ \\
\hline Left-Right & $\begin{array}{c}-0.148 * * * \\
(0.018)\end{array}$ & $\begin{array}{c}-0.144 * * * \\
(0.018)\end{array}$ & $\begin{array}{c}-0.161 * * * \\
(0.039)\end{array}$ & $\begin{array}{c}-0.154 * * * \\
(0.041)\end{array}$ & & \\
\hline $\begin{array}{l}\text { Region Dummies } \\
\text { Observations }\end{array}$ & $\begin{array}{c}\mathrm{N} \\
2340\end{array}$ & $\begin{array}{c}\mathrm{Y} \\
2340\end{array}$ & $\begin{array}{c}\mathrm{N} \\
2334\end{array}$ & $\begin{array}{c}\mathrm{Y} \\
2334\end{array}$ & $\begin{array}{c}\mathrm{N} \\
2338\end{array}$ & $\begin{array}{c}\mathrm{Y} \\
2338\end{array}$ \\
\hline \multicolumn{7}{|c|}{ Regionally clustered standard errors in parentheses $* * * \mathrm{p}<0.01,{ }^{* *} \mathrm{p}<0.05,{ }^{*} \mathrm{p}<0.1$} \\
\hline BSAS 2006 & $\begin{array}{c}\text { (1) } \\
\text { PENSIONS } \\
\end{array}$ & $\begin{array}{c}(2) \\
\text { PENSIONS } \\
\end{array}$ & $\begin{array}{c}(3) \\
\text { UNEMP }\end{array}$ & $\begin{array}{c}(4) \\
\text { UNEMP }\end{array}$ & $\begin{array}{c}(5) \\
\text { REDIST }\end{array}$ & $\begin{array}{c}(6) \\
\text { REDIST }\end{array}$ \\
\hline HomeOwn* \% 5yr & $\begin{array}{l}-0.180 \\
(0.144)\end{array}$ & $\begin{array}{c}-0.307 * * * \\
(0.094)\end{array}$ & $\begin{array}{c}-0.391 * * * \\
(0.124)\end{array}$ & $\begin{array}{c}-0.419 * * * \\
(0.122)\end{array}$ & $\begin{array}{c}-0.179 * * * \\
(0.049)\end{array}$ & $\begin{array}{c}-0.229 * * * \\
(0.053)\end{array}$ \\
\hline Gender & $\begin{array}{c}-0.020 \\
(0.080)\end{array}$ & $\begin{array}{c}-0.016 \\
(0.079)\end{array}$ & $\begin{array}{c}-0.102 * * \\
(0.044)\end{array}$ & $\begin{array}{c}-0.105^{* *} \\
(0.047)\end{array}$ & $\begin{array}{c}-0.115^{* * *} \\
(0.037)\end{array}$ & $\begin{array}{c}-0.115 * * * \\
(0.037)\end{array}$ \\
\hline Age & $\begin{array}{c}0.016 * * * \\
(0.004)\end{array}$ & $\begin{array}{c}0.016^{* * *} \\
(0.003)\end{array}$ & $\begin{array}{c}0.012 * * * \\
(0.003)\end{array}$ & $\begin{array}{c}0.012 * * * \\
(0.003)\end{array}$ & $\begin{array}{c}0.007 * * * \\
(0.001)\end{array}$ & $\begin{array}{c}0.007 * * * \\
(0.001)\end{array}$ \\
\hline Income & $\begin{array}{l}-0.007 \\
(0.016)\end{array}$ & $\begin{array}{c}-0.005 \\
(0.017)\end{array}$ & $\begin{array}{c}-0.062 * * * \\
(0.015)\end{array}$ & $\begin{array}{c}-0.061 * * * \\
(0.014)\end{array}$ & $\begin{array}{c}-0.044 * * * \\
(0.006)\end{array}$ & $\begin{array}{c}-0.042 * * * \\
(0.005)\end{array}$ \\
\hline Degree & $\begin{array}{c}-0.273^{*} \\
(0.140)\end{array}$ & $\begin{array}{c}-0.242 \\
(0.151)\end{array}$ & $\begin{array}{l}0.230^{*} \\
(0.118)\end{array}$ & $\begin{array}{c}0.211 \\
(0.130)\end{array}$ & $\begin{array}{c}0.338 * * * \\
(0.097)\end{array}$ & $\begin{array}{c}0.329 * * * \\
(0.097)\end{array}$ \\
\hline Retired & $\begin{array}{c}-0.208^{*} \\
(0.115)\end{array}$ & $\begin{array}{c}-0.210^{*} \\
(0.124)\end{array}$ & $\begin{array}{c}-0.274 * * \\
(0.118)\end{array}$ & $\begin{array}{c}-0.255^{* *} \\
(0.112)\end{array}$ & $\begin{array}{c}-0.283 * * * \\
(0.039)\end{array}$ & $\begin{array}{c}-0.275^{* * * *} \\
(0.038)\end{array}$ \\
\hline Left-Right & $\begin{array}{c}-0.248 * * * \\
(0.069)\end{array}$ & $\begin{array}{c}-0.242 * * * \\
(0.065)\end{array}$ & $\begin{array}{c}-0.178^{* *} \\
(0.079)\end{array}$ & $\begin{array}{c}-0.188 * * \\
(0.080)\end{array}$ & & \\
\hline Region Dummies & $\mathrm{N}$ & $\mathrm{Y}$ & $\mathrm{N}$ & $\mathrm{Y}$ & $\mathrm{N}$ & $\mathrm{Y}$ \\
\hline Observations & 712 & 712 & 686 & 686 & 3013 & 3013 \\
\hline
\end{tabular}

All models include dummies for occupation.

Regionally clustered standard errors in parentheses $* * * \mathrm{p}<0.01, * * \mathrm{p}<0.05,{ }^{*} \mathrm{p}<0.1$ 
Table Four (b): BSAS Partisan Differences with Pensions

\begin{tabular}{|c|c|c|c|c|c|c|c|c|}
\hline & (1) & (2) & (3) & (4) & (5) & (6) & (7) & (8) \\
\hline \multirow[t]{2}{*}{ VARIABLES } & 2001 & 2001 & 2001 & 2001 & 2006 & 2006 & 2006 & 2006 \\
\hline & CONS & LAB & CONS & LAB & CONS & LAB & CONS & LAB \\
\hline \multirow[t]{2}{*}{ HomeOwn* \% 5yr } & $-0.419 * * *$ & -0.222 & $-0.446 * *$ & -0.193 & $-0.824 * *$ & -0.055 & $-0.946^{* *}$ & -0.136 \\
\hline & $(0.117)$ & $(0.193)$ & $(0.182)$ & $(0.217)$ & $(0.380)$ & $(0.233)$ & $(0.434)$ & $(0.272)$ \\
\hline \multirow[t]{2}{*}{ Gender } & 0.054 & 0.065 & 0.058 & 0.070 & $0.273 * *$ & 0.043 & $0.253^{*}$ & 0.022 \\
\hline & $(0.083)$ & $(0.063)$ & $(0.085)$ & $(0.061)$ & $(0.107)$ & $(0.171)$ & $(0.130)$ & $(0.181)$ \\
\hline \multirow[t]{2}{*}{ Age } & $0.013 * * *$ & $0.012 * * *$ & $0.014 * * *$ & $0.012 * * *$ & $0.021 * * *$ & $0.014^{*}$ & $0.022 * *$ & $0.015^{*}$ \\
\hline & $(0.004)$ & $(0.003)$ & $(0.004)$ & $(0.003)$ & $(0.008)$ & $(0.008)$ & $(0.009)$ & $(0.008)$ \\
\hline \multirow[t]{2}{*}{ Income } & $-0.146 * * *$ & 0.001 & $-0.150 * * *$ & 0.004 & $-0.037 *$ & -0.005 & $-0.034 *$ & -0.007 \\
\hline & $(0.056)$ & $(0.043)$ & $(0.056)$ & $(0.041)$ & $(0.020)$ & $(0.027)$ & $(0.021)$ & $(0.029)$ \\
\hline \multirow[t]{2}{*}{ Degree } & -0.150 & -0.117 & -0.140 & -0.127 & -0.130 & -0.303 & -0.157 & -0.359 \\
\hline & $(0.100)$ & $(0.124)$ & $(0.116)$ & $(0.130)$ & $(0.267)$ & $(0.239)$ & $(0.289)$ & $(0.268)$ \\
\hline \multirow[t]{2}{*}{ Retired } & -0.224 & 0.040 & $-0.262 *$ & 0.052 & -0.533 & -0.064 & $-0.684 * *$ & 0.003 \\
\hline & $(0.138)$ & $(0.129)$ & $(0.134)$ & $(0.132)$ & $(0.325)$ & $(0.249)$ & $(0.333)$ & $(0.267)$ \\
\hline \multirow[t]{2}{*}{ Left-Right } & -0.018 & $-0.154 * * *$ & -0.008 & $-0.142 * * *$ & -0.103 & $-0.468 * * *$ & -0.123 & $-0.410 * * *$ \\
\hline & $(0.062)$ & $(0.057)$ & $(0.062)$ & $(0.055)$ & $(0.116)$ & $(0.104)$ & $(0.111)$ & $(0.113)$ \\
\hline \multirow[t]{2}{*}{ Skill Specificity } & 0.066 & 0.042 & 0.071 & 0.043 & & & & \\
\hline & $(0.090)$ & $(0.046)$ & $(0.090)$ & $(0.044)$ & & & & \\
\hline Region Dummies & $\mathrm{N}$ & $\mathrm{N}$ & $\mathrm{Y}$ & $\mathrm{Y}$ & $\mathrm{N}$ & $\mathrm{N}$ & $\mathrm{Y}$ & Y \\
\hline Observations & 529 & 1080 & 529 & 1080 & 193 & 236 & 193 & 236 \\
\hline
\end{tabular}

Models 5 to 8 use occupation dummies. Regionally clustered standard errors in parentheses $* * * \mathrm{p}<0.01, * * \mathrm{p}<0.05, * \mathrm{p}<0.1$ 
Table Five (a): British Household Panel Survey: Full Employment Policies

\begin{tabular}{|c|c|c|c|c|c|c|c|c|}
\hline & $\begin{array}{c}(1) \\
\text { LINEAR }\end{array}$ & $\begin{array}{c}(2) \\
\text { LINEAR }\end{array}$ & $\begin{array}{c}3) \\
\mathrm{LOG} \\
\end{array}$ & $\begin{array}{c}(4) \\
\text { LOG } \\
\end{array}$ & $\begin{array}{c}5) \\
\text { LINEAR }\end{array}$ & $\begin{array}{c}(6) \\
\text { LINEAR }\end{array}$ & $\begin{array}{c}(7) \\
\text { LOG } \\
\end{array}$ & $\begin{array}{c}(8) \\
\text { LOG }\end{array}$ \\
\hline Ch. House Price & $\begin{array}{c}-0.003^{* * *} \\
(0.001)\end{array}$ & $\begin{array}{l}-0.002^{*} \\
(0.001)\end{array}$ & $\begin{array}{c}-0.082^{* * *} \\
(0.022)\end{array}$ & $\begin{array}{l}-0.039^{*} \\
(0.023)\end{array}$ & $\begin{array}{c}-0.003^{* * *} \\
(0.001)\end{array}$ & $\begin{array}{l}-0.002^{*} \\
(0.001)\end{array}$ & $\begin{array}{c}-0.109^{* * *} \\
(0.032)\end{array}$ & $\begin{array}{l}-0.051 \\
(0.033)\end{array}$ \\
\hline Ch. Homeown & $\begin{array}{c}0.036 \\
(0.037)\end{array}$ & $\begin{array}{c}0.032 \\
(0.037)\end{array}$ & $\begin{array}{c}0.182^{* * *} \\
(0.060)\end{array}$ & $\begin{array}{c}0.098 \\
(0.060)\end{array}$ & $\begin{array}{c}0.034 \\
(0.053)\end{array}$ & $\begin{array}{c}0.026 \\
(0.053)\end{array}$ & $\begin{array}{c}0.232^{* * *} \\
(0.086)\end{array}$ & $\begin{array}{c}0.113 \\
(0.088)\end{array}$ \\
\hline Ch. Education & $\begin{array}{c}0.007 \\
(0.025)\end{array}$ & $\begin{array}{c}0.010 \\
(0.025)\end{array}$ & $\begin{array}{c}0.006 \\
(0.025)\end{array}$ & $\begin{array}{c}0.009 \\
(0.025)\end{array}$ & $\begin{array}{c}0.025 \\
(0.036)\end{array}$ & $\begin{array}{c}0.030 \\
(0.036)\end{array}$ & $\begin{array}{c}0.026 \\
(0.036)\end{array}$ & $\begin{array}{c}0.030 \\
(0.036)\end{array}$ \\
\hline Ch. Unemp & $\begin{array}{c}0.085^{*} \\
(0.044)\end{array}$ & $\begin{array}{c}0.083^{*} \\
(0.044)\end{array}$ & $\begin{array}{c}0.086^{*} \\
(0.044)\end{array}$ & $\begin{array}{c}0.083^{*} \\
(0.044)\end{array}$ & $\begin{array}{c}0.022 \\
(0.060)\end{array}$ & $\begin{array}{c}0.023 \\
(0.060)\end{array}$ & $\begin{array}{c}0.024 \\
(0.060)\end{array}$ & $\begin{array}{c}0.024 \\
(0.060)\end{array}$ \\
\hline Ch. Self Emp & $\begin{array}{c}-0.095^{* *} \\
(0.046)\end{array}$ & $\begin{array}{c}-0.096^{* *} \\
(0.045)\end{array}$ & $\begin{array}{c}-0.093^{* *} \\
(0.046)\end{array}$ & $\begin{array}{c}-0.095^{* *} \\
(0.045)\end{array}$ & $\begin{array}{c}-0.141^{* *} \\
(0.059)\end{array}$ & $\begin{array}{c}-0.142^{* *} \\
(0.059)\end{array}$ & $\begin{array}{c}-0.137^{* *} \\
(0.059)\end{array}$ & $\begin{array}{c}-0.140^{* *} \\
(0.059)\end{array}$ \\
\hline Ch. Non Emp & $\begin{array}{c}0.034 \\
(0.030)\end{array}$ & $\begin{array}{c}0.033 \\
(0.030)\end{array}$ & $\begin{array}{c}0.035 \\
(0.030)\end{array}$ & $\begin{array}{c}0.033 \\
(0.030)\end{array}$ & $\begin{array}{c}0.033 \\
(0.042)\end{array}$ & $\begin{array}{c}0.033 \\
(0.042)\end{array}$ & $\begin{array}{c}0.035 \\
(0.042)\end{array}$ & $\begin{array}{c}0.034 \\
(0.042)\end{array}$ \\
\hline Ch. Retired & $\begin{array}{c}0.044 \\
(0.040)\end{array}$ & $\begin{array}{c}0.048 \\
(0.040)\end{array}$ & $\begin{array}{c}0.044 \\
(0.040)\end{array}$ & $\begin{array}{c}0.048 \\
(0.040)\end{array}$ & $\begin{array}{c}0.063 \\
(0.050)\end{array}$ & $\begin{array}{c}0.068 \\
(0.050)\end{array}$ & $\begin{array}{c}0.064 \\
(0.050)\end{array}$ & $\begin{array}{c}0.068 \\
(0.050)\end{array}$ \\
\hline Ch. Income & $\begin{array}{c}-0.002 \\
(0.008)\end{array}$ & $\begin{array}{c}-0.000 \\
(0.008)\end{array}$ & $\begin{array}{c}-0.002 \\
(0.008)\end{array}$ & $\begin{array}{c}-0.000 \\
(0.008)\end{array}$ & $\begin{array}{l}-0.001 \\
(0.010)\end{array}$ & $\begin{array}{l}-0.000 \\
(0.010)\end{array}$ & $\begin{array}{c}-0.001 \\
(0.010)\end{array}$ & $\begin{array}{l}-0.000 \\
(0.010)\end{array}$ \\
\hline Ch. Children & $\begin{array}{l}-0.007 \\
(0.016)\end{array}$ & $\begin{array}{c}-0.009 \\
(0.016)\end{array}$ & $\begin{array}{l}-0.005 \\
(0.016)\end{array}$ & $\begin{array}{c}-0.008 \\
(0.016)\end{array}$ & $\begin{array}{l}-0.038^{*} \\
(0.023)\end{array}$ & $\begin{array}{l}-0.041^{*} \\
(0.022)\end{array}$ & $\begin{array}{c}-0.036 \\
(0.023)\end{array}$ & $\begin{array}{l}-0.040^{*} \\
(0.023)\end{array}$ \\
\hline Gender & $\begin{array}{c}-0.023^{* *} \\
(0.011)\end{array}$ & $\begin{array}{c}-0.024^{* *} \\
(0.011)\end{array}$ & $\begin{array}{c}-0.024^{* *} \\
(0.011)\end{array}$ & $\begin{array}{c}-0.024^{* *} \\
(0.011)\end{array}$ & $\begin{array}{l}-0.024 \\
(0.015)\end{array}$ & $\begin{array}{l}-0.024 \\
(0.015)\end{array}$ & $\begin{array}{l}-0.025^{*} \\
(0.015)\end{array}$ & $\begin{array}{l}-0.024 \\
(0.015)\end{array}$ \\
\hline Age & $\begin{array}{c}0.002^{* * *} \\
(0.000)\end{array}$ & $\begin{array}{c}0.002^{* * *} \\
(0.000)\end{array}$ & $\begin{array}{c}0.002^{* * *} \\
(0.000)\end{array}$ & $\begin{array}{c}0.002^{* * *} \\
(0.000)\end{array}$ & $\begin{array}{c}0.002^{* * *} \\
(0.000)\end{array}$ & $\begin{array}{c}0.002^{* * *} \\
(0.000)\end{array}$ & $\begin{array}{c}0.002^{* * *} \\
(0.000)\end{array}$ & $\begin{array}{c}0.002^{* * *} \\
(0.000)\end{array}$ \\
\hline Ch. Partisan & & & & & $\begin{array}{c}-0.077^{* * *} \\
(0.024)\end{array}$ & $\begin{array}{c}-0.076^{* * *} \\
(0.024)\end{array}$ & $\begin{array}{c}-0.076^{* * *} \\
(0.024)\end{array}$ & $\begin{array}{c}-0.075^{* * *} \\
(0.024)\end{array}$ \\
\hline Year & $\begin{array}{c}-0.020^{* * *} \\
(0.002)\end{array}$ & & $\begin{array}{c}-0.018^{* * *} \\
(0.002)\end{array}$ & & $\begin{array}{c}-0.018^{* * *} \\
(0.002)\end{array}$ & & $\begin{array}{c}-0.016^{* * *} \\
(0.002)\end{array}$ & \\
\hline $\begin{array}{l}\text { Time } \\
\text { Region } \\
N \\
\end{array}$ & $\begin{array}{c}\text { Year } \\
\mathrm{N} \\
50907\end{array}$ & $\begin{array}{c}\text { Dummy } \\
\mathrm{N} \\
50907 \\
\end{array}$ & $\begin{array}{c}\text { Year } \\
\mathrm{N} \\
50907\end{array}$ & $\begin{array}{c}\text { Dummy } \\
\mathrm{N} \\
50907 \\
\end{array}$ & $\begin{array}{c}\text { Year } \\
\text { Y } \\
30810 \\
\end{array}$ & $\begin{array}{c}\text { Dummy } \\
\text { Y } \\
30810 \\
\end{array}$ & $\begin{array}{c}\text { Year } \\
\text { Y } \\
30810 \\
\end{array}$ & $\begin{array}{c}\text { Dummy } \\
\mathrm{Y} \\
30810 \\
\end{array}$ \\
\hline
\end{tabular}

Panel clustered standard errors in parentheses ${ }^{*} p<.1,{ }^{* *} p<.05,{ }^{* * *} p<.01$.

All regressions are ordered logit models. 
Table Five (b): British Household Panel Survey: Compound Policy Preferences

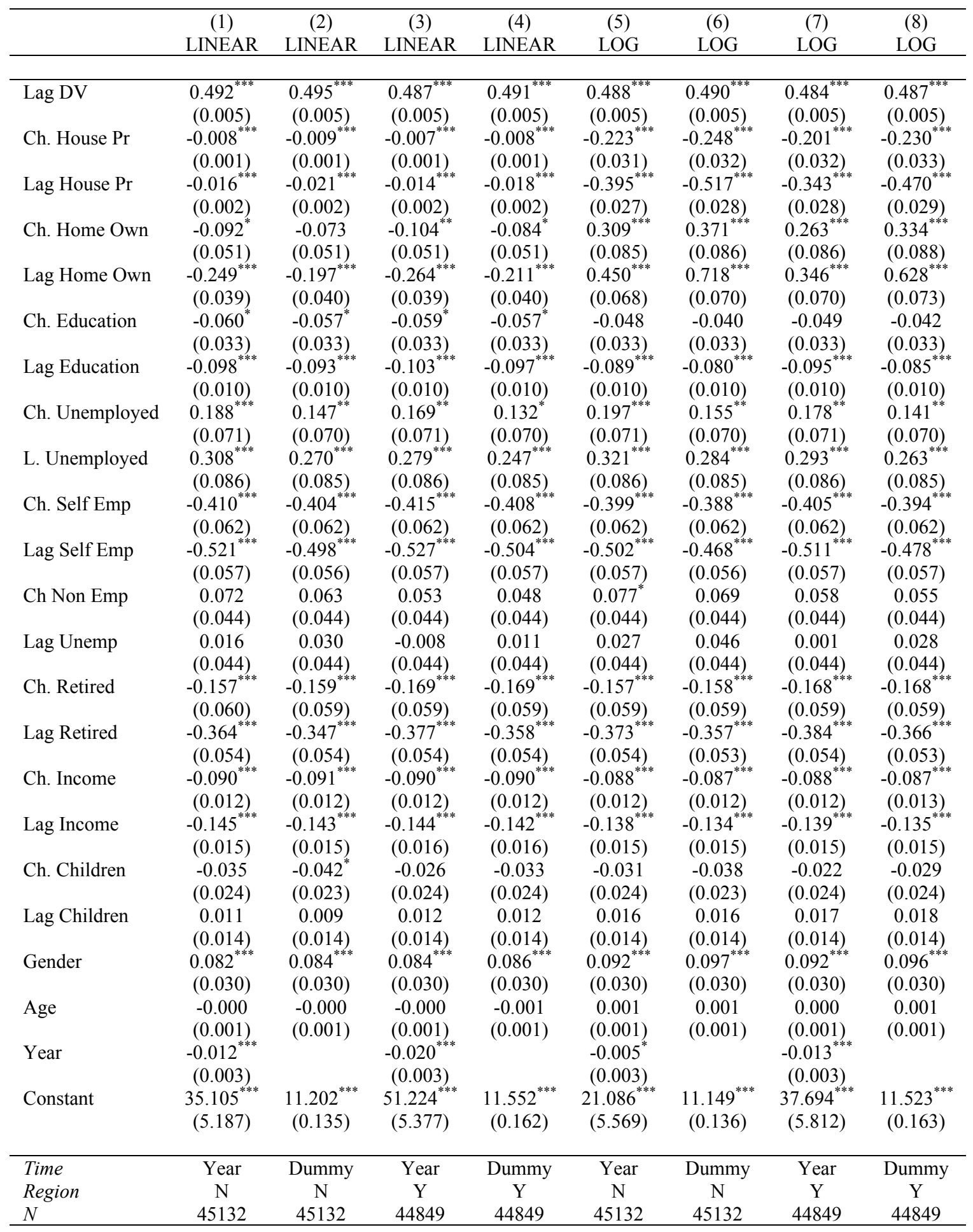

Panel clustered standard errors in parentheses ${ }^{*} p<.1,{ }^{* *} p<.05,{ }^{* * *} p<.01$. All regressions are linear with panel random effects 
Table Six: German ALLBUS Data

\begin{tabular}{|c|c|c|c|c|c|c|}
\hline & $\begin{array}{c}(1) \\
\text { BENEFITS }\end{array}$ & $\begin{array}{c}(2) \\
\text { BENEFITS }\end{array}$ & $\begin{array}{c}(3) \\
\text { INC SUPP }\end{array}$ & $\begin{array}{c}(4) \\
\text { INC SUPP }\end{array}$ & $\begin{array}{c}(5) \\
\text { GAP JUST }\end{array}$ & $\begin{array}{c}(6) \\
\text { GAP JUST }\end{array}$ \\
\hline Own House & $\begin{array}{c}-0.280 * * * \\
(0.086)\end{array}$ & $\begin{array}{c}-0.274 * * * \\
(0.094)\end{array}$ & $\begin{array}{c}-0.155^{* * *} \\
(0.048)\end{array}$ & $\begin{array}{c}-0.225^{* * *} \\
(0.056)\end{array}$ & $\begin{array}{c}0.187 * * * \\
(0.070)\end{array}$ & $\begin{array}{l}0.135^{*} \\
(0.078)\end{array}$ \\
\hline Own House*\%5 Yr & $\begin{array}{c}-0.922 * \\
(0.562)\end{array}$ & $\begin{array}{l}-0.338 \\
(0.723)\end{array}$ & $\begin{array}{c}-1.048 * * \\
(0.419)\end{array}$ & $\begin{array}{c}-1.472 * * \\
(0.629)\end{array}$ & $\begin{array}{c}1.984 * * * \\
(0.424)\end{array}$ & $\begin{array}{l}1.180^{*} \\
(0.723)\end{array}$ \\
\hline Age & $\begin{array}{c}-0.016^{* * *} \\
(0.002)\end{array}$ & $\begin{array}{c}-0.025^{* * *} \\
(0.004)\end{array}$ & $\begin{array}{c}-0.006^{* * *} \\
(0.002)\end{array}$ & $\begin{array}{l}-0.001 \\
(0.004)\end{array}$ & $\begin{array}{c}0.009 * * * \\
(0.002)\end{array}$ & $\begin{array}{c}0.012 * * * \\
(0.003)\end{array}$ \\
\hline Gender & $\begin{array}{c}0.343 * * * \\
(0.048)\end{array}$ & $\begin{array}{c}0.120 \\
(0.103)\end{array}$ & $\begin{array}{c}0.141 * * * \\
(0.049)\end{array}$ & $\begin{array}{l}0.125^{*} \\
(0.068)\end{array}$ & $\begin{array}{c}-0.143 * * * \\
(0.032)\end{array}$ & $\begin{array}{l}-0.083 \\
(0.068)\end{array}$ \\
\hline Income & $\begin{array}{c}-0.093 * * * \\
(0.010)\end{array}$ & $\begin{array}{c}-0.063 * * * \\
(0.015)\end{array}$ & $\begin{array}{c}-0.079 * * * \\
(0.005)\end{array}$ & $\begin{array}{c}-0.047 * * * \\
(0.009)\end{array}$ & $\begin{array}{c}0.068 * * * \\
(0.008)\end{array}$ & $\begin{array}{c}0.030 * * * \\
(0.009)\end{array}$ \\
\hline Left-Right & $\begin{array}{c}-0.214 * * * \\
(0.022)\end{array}$ & $\begin{array}{c}-0.124 * * * \\
(0.027)\end{array}$ & $\begin{array}{c}-0.089 * * * \\
(0.014)\end{array}$ & $\begin{array}{l}-0.026 \\
(0.027)\end{array}$ & $\begin{array}{c}0.196 * * * \\
(0.013)\end{array}$ & $\begin{array}{c}0.107 * * * \\
(0.022)\end{array}$ \\
\hline Retired & $\begin{array}{c}0.178 * * * \\
(0.057)\end{array}$ & $\begin{array}{l}-0.044 \\
(0.108)\end{array}$ & $\begin{array}{c}0.257 * * * \\
(0.056)\end{array}$ & $\begin{array}{l}-0.049 \\
(0.100)\end{array}$ & $\begin{array}{l}-0.069 \\
(0.088)\end{array}$ & $\begin{array}{c}0.132 \\
(0.102)\end{array}$ \\
\hline Education & $\begin{array}{c}-0.205^{* * *} \\
(0.017)\end{array}$ & $\begin{array}{c}-0.212 * * * \\
(0.060)\end{array}$ & $\begin{array}{c}-0.183^{* * *} \\
(0.020)\end{array}$ & $\begin{array}{c}-0.116^{* * *} \\
(0.041)\end{array}$ & $\begin{array}{l}0.030^{*} \\
(0.018)\end{array}$ & $\begin{array}{c}0.120 * * * \\
(0.025)\end{array}$ \\
\hline Skill Specificity & & $\begin{array}{c}0.057 \\
(0.057)\end{array}$ & & $\begin{array}{c}0.064 \\
(0.045)\end{array}$ & & $\begin{array}{c}-0.137 * * * \\
(0.033)\end{array}$ \\
\hline Bundesland Dummies & $\mathrm{N}$ & Y & $\mathrm{N}$ & Y & $\mathrm{N}$ & $\mathrm{Y}$ \\
\hline Observations & 6137 & 2454 & 9908 & 3063 & 13777 & 3946 \\
\hline
\end{tabular}

Bundesland clustered standard errors in parentheses *** $\mathrm{p}<0.01,{ }^{* *} \mathrm{p}<0.05,{ }^{*} \mathrm{p}<0.1$ 
Table Seven (a): Total Social Spending 1980 to 2001

\begin{tabular}{|c|c|c|c|c|c|c|}
\hline & $\begin{array}{c}\text { (1) } \\
\text { FIXED FX }\end{array}$ & $\begin{array}{c}\text { (2) } \\
\text { FIXED FX }\end{array}$ & $\begin{array}{c}\text { (3) } \\
\text { FIXED AR1 }\end{array}$ & $\begin{array}{c}(4) \\
\text { FIXED LDV }\end{array}$ & $\begin{array}{c}(5) \\
\text { POOLED }\end{array}$ & $\begin{array}{c}(6) \\
\text { PCSE }\end{array}$ \\
\hline Lagged DV & & & & $\begin{array}{c}0.826 * * * \\
(0.040)\end{array}$ & $\begin{array}{c}0.961 * * * \\
(0.015)\end{array}$ & $\begin{array}{c}0.950 * * * \\
(0.018)\end{array}$ \\
\hline House Price Change & $\begin{array}{c}-0.536 \\
(0.500)\end{array}$ & $\begin{array}{l}-0.608 \\
(0.519)\end{array}$ & $\begin{array}{l}-0.417 \\
(0.455)\end{array}$ & $\begin{array}{l}-0.352 \\
(0.218)\end{array}$ & $\begin{array}{c}0.067 \\
(0.202)\end{array}$ & $\begin{array}{l}-0.028 \\
(0.214)\end{array}$ \\
\hline Cabinet Partisanship & $\begin{array}{c}0.001 \\
(0.005)\end{array}$ & $\begin{array}{c}0.002 \\
(0.004)\end{array}$ & $\begin{array}{l}-0.004 \\
(0.002)\end{array}$ & $\begin{array}{l}-0.001 \\
(0.002)\end{array}$ & $\begin{array}{l}-0.003 * \\
(0.002)\end{array}$ & $\begin{array}{c}-0.003 * * \\
(0.002)\end{array}$ \\
\hline Partisan*House Price & $\begin{array}{c}-0.039 * * * \\
(0.010)\end{array}$ & $\begin{array}{c}-0.042 * * * \\
(0.009)\end{array}$ & $\begin{array}{c}-0.026 * * * \\
(0.008)\end{array}$ & $\begin{array}{c}-0.018 * * \\
(0.007)\end{array}$ & $\begin{array}{c}-0.015^{* * *} \\
(0.004)\end{array}$ & $\begin{array}{c}-0.016^{* * * *} \\
(0.004)\end{array}$ \\
\hline GDP per capita & $\begin{array}{l}-0.052 \\
(0.182)\end{array}$ & $\begin{array}{l}-0.045 \\
(0.254)\end{array}$ & $\begin{array}{c}-0.620 * * * \\
(0.189)\end{array}$ & $\begin{array}{c}0.084 \\
(0.092)\end{array}$ & $\begin{array}{c}-0.060 * * * \\
(0.021)\end{array}$ & $\begin{array}{c}-0.063^{* *} \\
(0.027)\end{array}$ \\
\hline GDP growth & $\begin{array}{c}-0.278 * * * \\
(0.056)\end{array}$ & $\begin{array}{c}-0.218^{* * * *} \\
(0.044)\end{array}$ & $\begin{array}{l}-0.051^{*} \\
(0.027)\end{array}$ & $\begin{array}{c}-0.225^{* * *} \\
(0.032)\end{array}$ & $\begin{array}{c}-0.216^{* * *} \\
(0.024)\end{array}$ & $\begin{array}{c}-0.244 * * * \\
(0.025)\end{array}$ \\
\hline Population (ln) & $\begin{array}{c}6.837 \\
(6.927)\end{array}$ & $\begin{array}{l}10.252 \\
(9.129)\end{array}$ & $\begin{array}{c}0.548 \\
(1.998)\end{array}$ & $\begin{array}{c}2.560 \\
(3.524)\end{array}$ & $\begin{array}{c}0.031 \\
(0.054)\end{array}$ & $\begin{array}{c}0.027 \\
(0.068)\end{array}$ \\
\hline Unemployment & $\begin{array}{c}0.450 * * * \\
(0.099)\end{array}$ & $\begin{array}{c}0.462 * * * \\
(0.109)\end{array}$ & $\begin{array}{c}0.190 * * * \\
(0.065)\end{array}$ & $\begin{array}{c}0.020 \\
(0.044)\end{array}$ & $\begin{array}{c}-0.042 * * * \\
(0.015)\end{array}$ & $\begin{array}{c}-0.039 * * \\
(0.015)\end{array}$ \\
\hline Real Interest rate & & $\begin{array}{c}0.081 \\
(0.069)\end{array}$ & $\begin{array}{c}0.059 * * \\
(0.026)\end{array}$ & $\begin{array}{c}0.071 * * * \\
(0.021)\end{array}$ & $\begin{array}{c}0.051 * * * \\
(0.018)\end{array}$ & $\begin{array}{c}0.058 * * * \\
(0.021)\end{array}$ \\
\hline Inflation & & $\begin{array}{c}0.028 \\
(0.082)\end{array}$ & $\begin{array}{l}-0.049 \\
(0.032)\end{array}$ & $\begin{array}{l}-0.004 \\
(0.029)\end{array}$ & $\begin{array}{l}-0.002 \\
(0.020)\end{array}$ & $\begin{array}{l}-0.024 \\
(0.023)\end{array}$ \\
\hline Trade & & $\begin{array}{l}-0.053 \\
(0.031)\end{array}$ & $\begin{array}{c}-0.032 * * \\
(0.016)\end{array}$ & $\begin{array}{l}-0.022 * \\
(0.011)\end{array}$ & $\begin{array}{l}-0.002 \\
(0.002)\end{array}$ & $\begin{array}{l}-0.002 \\
(0.002)\end{array}$ \\
\hline Population $>65$ & & $\begin{array}{l}-0.087 \\
(0.231)\end{array}$ & $\begin{array}{l}-0.239 \\
(0.290)\end{array}$ & $\begin{array}{l}-0.010 \\
(0.061)\end{array}$ & $\begin{array}{c}0.052 \\
(0.033)\end{array}$ & $\begin{array}{l}0.066^{*} \\
(0.035)\end{array}$ \\
\hline Constant & $\begin{array}{c}-95.038 \\
(116.811)\end{array}$ & $\begin{array}{l}-148.366 \\
(152.261)\end{array}$ & $\begin{array}{c}-4.059 * * * \\
(0.628)\end{array}$ & $\begin{array}{l}-40.063 \\
(58.631)\end{array}$ & $\begin{array}{c}1.479 \\
(1.023)\end{array}$ & $\begin{array}{c}22.539 \\
(38.094)\end{array}$ \\
\hline Observations & 333 & 298 & 280 & 281 & 281 & 281 \\
\hline R-squared & 0.712 & 0.736 & 0.589 & 0.914 & 0.992 & 0.993 \\
\hline Number of ccode & 18 & 18 & 18 & 18 & 18 & 18 \\
\hline
\end{tabular}

All models, except Model 6, contain year dummies. Country clustered robust standard errors in parentheses $* * * \mathrm{p}<0.01, * * \mathrm{p}<0.05, * \mathrm{p}<0.1$ 
Table Seven (b): Total Pensions Spending 1980 to 2001

\begin{tabular}{|c|c|c|c|c|c|c|}
\hline & $\begin{array}{c}\text { (1) } \\
\text { FIXED FX }\end{array}$ & $\begin{array}{c}(2) \\
\text { FIXED FX }\end{array}$ & $\begin{array}{c}\text { (3) } \\
\text { FIXED AR1 }\end{array}$ & $\begin{array}{c}\text { (4) } \\
\text { FIXED LDV }\end{array}$ & $\begin{array}{c}(5) \\
\text { POOLED }\end{array}$ & $\begin{array}{c}(6) \\
\text { PCSE }\end{array}$ \\
\hline Lagged DV & & & & $\begin{array}{c}0.858 * * * \\
(0.050)\end{array}$ & $\begin{array}{c}0.981 * * * \\
(0.012)\end{array}$ & $\begin{array}{c}0.982 * * * \\
(0.011)\end{array}$ \\
\hline House Price Change & $\begin{array}{l}-0.324 \\
(0.283)\end{array}$ & $\begin{array}{l}-0.293 \\
(0.250)\end{array}$ & $\begin{array}{l}-0.302 \\
(0.186)\end{array}$ & $\begin{array}{l}-0.064 \\
(0.107)\end{array}$ & $\begin{array}{c}0.102 \\
(0.085)\end{array}$ & $\begin{array}{c}0.056 \\
(0.071)\end{array}$ \\
\hline Cabinet Partisanship & $\begin{array}{c}0.001 \\
(0.002)\end{array}$ & $\begin{array}{c}0.001 \\
(0.002)\end{array}$ & $\begin{array}{l}-0.001 \\
(0.001)\end{array}$ & $\begin{array}{c}0.001 \\
(0.001)\end{array}$ & $\begin{array}{l}-0.000 \\
(0.001)\end{array}$ & $\begin{array}{l}-0.000 \\
(0.001)\end{array}$ \\
\hline Partisan*House Price & $\begin{array}{c}-0.013 * * * \\
(0.003)\end{array}$ & $\begin{array}{c}-0.013 * * * \\
(0.003)\end{array}$ & $\begin{array}{c}-0.008 * * \\
(0.003)\end{array}$ & $\begin{array}{l}-0.005^{*} \\
(0.003)\end{array}$ & $\begin{array}{c}-0.006^{* * *} \\
(0.002)\end{array}$ & $\begin{array}{c}-0.006 * * * \\
(0.002)\end{array}$ \\
\hline GDP per capita & $\begin{array}{c}0.049 \\
(0.116)\end{array}$ & $\begin{array}{l}-0.018 \\
(0.107)\end{array}$ & $\begin{array}{c}-0.180 * * \\
(0.077)\end{array}$ & $\begin{array}{l}-0.004 \\
(0.039)\end{array}$ & $\begin{array}{c}-0.019 * * \\
(0.008)\end{array}$ & $\begin{array}{l}-0.017^{*} \\
(0.009)\end{array}$ \\
\hline GDP growth & $\begin{array}{c}-0.115^{* * *} \\
(0.034)\end{array}$ & $\begin{array}{c}-0.087 * * * \\
(0.019)\end{array}$ & $\begin{array}{l}-0.017 \\
(0.011)\end{array}$ & $\begin{array}{c}-0.059 * * * \\
(0.012)\end{array}$ & $\begin{array}{c}-0.059 * * * \\
(0.008)\end{array}$ & $\begin{array}{c}-0.063 * * * \\
(0.007)\end{array}$ \\
\hline Population (ln) & $\begin{array}{l}-7.337 \\
(4.336)\end{array}$ & $\begin{array}{l}-5.198 \\
(4.317)\end{array}$ & $\begin{array}{c}0.132 \\
(0.829)\end{array}$ & $\begin{array}{l}-1.167 \\
(1.168)\end{array}$ & $\begin{array}{c}0.053 * * * \\
(0.020)\end{array}$ & $\begin{array}{c}0.053 * * \\
(0.023)\end{array}$ \\
\hline Unemployment & $\begin{array}{c}0.115^{* * * *} \\
(0.034)\end{array}$ & $\begin{array}{c}0.104 * * \\
(0.036)\end{array}$ & $\begin{array}{c}0.013 \\
(0.027)\end{array}$ & $\begin{array}{l}-0.013 \\
(0.013)\end{array}$ & $\begin{array}{l}-0.012 * \\
(0.007)\end{array}$ & $\begin{array}{l}-0.009 \\
(0.007)\end{array}$ \\
\hline Real Interest rate & & $\begin{array}{c}0.004 \\
(0.030)\end{array}$ & $\begin{array}{l}0.024 * * \\
(0.011)\end{array}$ & $\begin{array}{l}0.020^{*} \\
(0.010)\end{array}$ & $\begin{array}{c}0.007 \\
(0.006)\end{array}$ & $\begin{array}{c}0.008 \\
(0.006)\end{array}$ \\
\hline Inflation & & $\begin{array}{l}0.020 \\
(0.026)\end{array}$ & $\begin{array}{l}-0.013 \\
(0.013)\end{array}$ & $\begin{array}{c}0.012 \\
(0.011)\end{array}$ & $\begin{array}{c}0.011 \\
(0.008)\end{array}$ & $\begin{array}{c}0.009 \\
(0.007)\end{array}$ \\
\hline Trade & & $\begin{array}{l}-0.012 \\
(0.022)\end{array}$ & $\begin{array}{l}-0.009 \\
(0.006)\end{array}$ & $\begin{array}{l}-0.003 \\
(0.004)\end{array}$ & $\begin{array}{l}-0.001 \\
(0.001)\end{array}$ & $\begin{array}{l}-0.001 \\
(0.001)\end{array}$ \\
\hline Population $>65$ & & $\begin{array}{c}0.222 \\
(0.130)\end{array}$ & $\begin{array}{c}0.129 \\
(0.119)\end{array}$ & $\begin{array}{c}0.040 \\
(0.028)\end{array}$ & $\begin{array}{c}0.029 * * \\
(0.013)\end{array}$ & $\begin{array}{c}0.026^{* *} \\
(0.013)\end{array}$ \\
\hline Constant & $\begin{array}{l}128.416^{*} \\
(70.603)\end{array}$ & $\begin{array}{c}91.415 \\
(70.018)\end{array}$ & $\begin{array}{c}-1.635^{* * *} \\
(0.255)\end{array}$ & $\begin{array}{c}20.307 \\
(19.145)\end{array}$ & $\begin{array}{l}-0.601 \\
(0.398)\end{array}$ & $\begin{array}{l}-13.049 \\
(9.155)\end{array}$ \\
\hline Observations & 333 & 298 & 280 & 281 & 281 & 281 \\
\hline R-squared & 0.565 & 0.619 & 0.400 & 0.878 & 0.993 & 0.993 \\
\hline Number of ccode & 18 & 18 & 18 & 18 & 18 & 18 \\
\hline
\end{tabular}

All models, except Model 6, contain year dummies. Country clustered robust standard errors in parentheses $* * * \mathrm{p}<0.01, * * \mathrm{p}<0.05, * \mathrm{p}<0.1$ 
Table Seven (c): Total Unemployment Spending 1980 to 2001

\begin{tabular}{|c|c|c|c|c|c|c|}
\hline & $\begin{array}{c}(1) \\
\text { FIXED FX }\end{array}$ & $\begin{array}{c}(2) \\
\text { FIXED FX }\end{array}$ & $\begin{array}{c}\text { (3) } \\
\text { FIXED AR1 }\end{array}$ & $\begin{array}{c}\text { (4) } \\
\text { FIXED LDV }\end{array}$ & $\begin{array}{c}(5) \\
\text { POOLED }\end{array}$ & $\begin{array}{c}(6) \\
\text { PCSE }\end{array}$ \\
\hline Lagged DV & & & & $\begin{array}{c}0.708 * * * \\
(0.063)\end{array}$ & $\begin{array}{c}0.890 * * * \\
(0.026)\end{array}$ & $\begin{array}{c}0.863 * * * \\
(0.036)\end{array}$ \\
\hline House Price Change & $\begin{array}{c}0.107 \\
(0.145)\end{array}$ & $\begin{array}{c}0.130 \\
(0.153)\end{array}$ & $\begin{array}{c}0.006 \\
(0.148)\end{array}$ & $\begin{array}{c}0.047 \\
(0.107)\end{array}$ & $\begin{array}{c}0.026 \\
(0.081)\end{array}$ & $\begin{array}{c}0.032 \\
(0.079)\end{array}$ \\
\hline Cabinet Partisanship & $\begin{array}{c}0.000 \\
(0.001)\end{array}$ & $\begin{array}{c}0.001 \\
(0.001)\end{array}$ & $\begin{array}{c}0.001 \\
(0.001)\end{array}$ & $\begin{array}{c}0.000 \\
(0.000)\end{array}$ & $\begin{array}{l}-0.001 \\
(0.001)\end{array}$ & $\begin{array}{l}-0.001 \\
(0.001)\end{array}$ \\
\hline Partisan*House Price & $\begin{array}{l}-0.006 \\
(0.004)\end{array}$ & $\begin{array}{l}-0.007 \\
(0.004)\end{array}$ & $\begin{array}{l}-0.002 \\
(0.003)\end{array}$ & $\begin{array}{l}-0.006^{*} \\
(0.003)\end{array}$ & $\begin{array}{c}-0.004 * * \\
(0.002)\end{array}$ & $\begin{array}{l}-0.004^{*} \\
(0.002)\end{array}$ \\
\hline GDP per capita & $\begin{array}{l}-0.016 \\
(0.055)\end{array}$ & $\begin{array}{l}-0.026 \\
(0.056)\end{array}$ & $\begin{array}{l}-0.100^{*} \\
(0.057)\end{array}$ & $\begin{array}{c}0.033 \\
(0.019)\end{array}$ & $\begin{array}{l}-0.002 \\
(0.008)\end{array}$ & $\begin{array}{c}0.005 \\
(0.010)\end{array}$ \\
\hline GDP growth & $\begin{array}{c}-0.026 * * \\
(0.011)\end{array}$ & $\begin{array}{l}-0.009 \\
(0.013)\end{array}$ & $\begin{array}{l}-0.000 \\
(0.009)\end{array}$ & $\begin{array}{c}-0.056^{* * * *} \\
(0.009)\end{array}$ & $\begin{array}{c}-0.067 * * * \\
(0.007)\end{array}$ & $\begin{array}{c}-0.076 * * * \\
(0.007)\end{array}$ \\
\hline Population (ln) & $\begin{array}{c}2.501 \\
(1.899)\end{array}$ & $\begin{array}{c}1.731 \\
(1.841)\end{array}$ & $\begin{array}{c}0.300 \\
(0.487)\end{array}$ & $\begin{array}{c}0.548 \\
(0.810)\end{array}$ & $\begin{array}{l}-0.029 \\
(0.023)\end{array}$ & $\begin{array}{l}-0.045^{*} \\
(0.027)\end{array}$ \\
\hline Unemployment & $\begin{array}{c}0.219 * * * \\
(0.034)\end{array}$ & $\begin{array}{c}0.232 * * * \\
(0.033)\end{array}$ & $\begin{array}{c}0.149 * * * \\
(0.021)\end{array}$ & $\begin{array}{c}0.075 * * * \\
(0.021)\end{array}$ & $\begin{array}{c}0.015 \\
(0.009)\end{array}$ & $\begin{array}{l}0.024 * * \\
(0.012)\end{array}$ \\
\hline Real Interest rate & & $\begin{array}{c}0.021 \\
(0.014)\end{array}$ & $\begin{array}{c}0.017 * * \\
(0.008)\end{array}$ & $\begin{array}{c}0.025 * * * \\
(0.008)\end{array}$ & $\begin{array}{c}0.019 * * * \\
(0.006)\end{array}$ & $\begin{array}{c}0.019 * * * \\
(0.006)\end{array}$ \\
\hline Inflation & & $\begin{array}{c}0.031 \\
(0.027)\end{array}$ & $\begin{array}{l}-0.007 \\
(0.011)\end{array}$ & $\begin{array}{c}0.010 \\
(0.013)\end{array}$ & $\begin{array}{l}-0.011 \\
(0.008)\end{array}$ & $\begin{array}{l}-0.012 \\
(0.008)\end{array}$ \\
\hline Trade & & $\begin{array}{c}-0.014 * * \\
(0.005)\end{array}$ & $\begin{array}{l}-0.003 \\
(0.005)\end{array}$ & $\begin{array}{l}-0.004 \\
(0.005)\end{array}$ & $\begin{array}{c}0.000 \\
(0.001)\end{array}$ & $\begin{array}{c}0.000 \\
(0.001)\end{array}$ \\
\hline Population $>65$ & & $\begin{array}{l}-0.117 \\
(0.075)\end{array}$ & $\begin{array}{c}-0.188^{* *} \\
(0.081)\end{array}$ & $\begin{array}{c}-0.070 * * \\
(0.029)\end{array}$ & $\begin{array}{c}0.003 \\
(0.008)\end{array}$ & $\begin{array}{c}0.005 \\
(0.010)\end{array}$ \\
\hline Constant & $\begin{array}{l}-42.091 \\
(31.741)\end{array}$ & $\begin{array}{l}-26.540 \\
(30.968)\end{array}$ & $\begin{array}{c}-1.080^{* * * *} \\
(0.220)\end{array}$ & $\begin{array}{c}-9.050 \\
(13.496)\end{array}$ & $\begin{array}{c}0.740^{* *} \\
(0.360)\end{array}$ & $\begin{array}{c}32.568 * * * \\
(10.941)\end{array}$ \\
\hline Observations & 330 & 295 & 277 & 279 & 279 & 279 \\
\hline R-squared & 0.709 & 0.722 & 0.551 & 0.871 & 0.949 & 0.941 \\
\hline Number of ccode & 18 & 18 & 18 & 18 & 18 & 18 \\
\hline
\end{tabular}

All models, except Model 6, contain year dummies. Country clustered robust standard errors in parentheses $* * * \mathrm{p}<0.01, * * \mathrm{p}<0.05, * \mathrm{p}<0.1$ 
Table Seven (d): Total Social Transfers 1975 to 2000

\begin{tabular}{|c|c|c|c|c|c|c|}
\hline & $\begin{array}{c}(1) \\
\text { FIXED FX }\end{array}$ & $\begin{array}{c}\text { (2) } \\
\text { FIXED FX }\end{array}$ & $\begin{array}{c}\text { (3) } \\
\text { FIXED AR1 }\end{array}$ & $\begin{array}{c}(4) \\
\text { FIXED LDV }\end{array}$ & $\begin{array}{c}5) \\
\text { POOLED }\end{array}$ & $\begin{array}{c}(6) \\
\text { PCSE }\end{array}$ \\
\hline Lagged DV & & & & $\begin{array}{c}0.930 * * * \\
(0.026)\end{array}$ & $\begin{array}{c}0.924 * * * \\
(0.025)\end{array}$ & $\begin{array}{c}0.923 * * * \\
(0.028)\end{array}$ \\
\hline House Price Change & $\begin{array}{l}-0.205 \\
(0.814)\end{array}$ & $\begin{array}{l}-0.652 \\
(0.858)\end{array}$ & $\begin{array}{l}-0.546 \\
(0.485)\end{array}$ & $\begin{array}{l}-0.097 \\
(0.206)\end{array}$ & $\begin{array}{c}0.032 \\
(0.260)\end{array}$ & $\begin{array}{c}0.165 \\
(0.276)\end{array}$ \\
\hline Cabinet Partisanship & $\begin{array}{l}0.007^{*} \\
(0.004)\end{array}$ & $\begin{array}{c}0.006 \\
(0.004)\end{array}$ & $\begin{array}{l}-0.002 \\
(0.003)\end{array}$ & $\begin{array}{l}-0.000 \\
(0.001)\end{array}$ & $\begin{array}{l}-0.002 \\
(0.001)\end{array}$ & $\begin{array}{l}-0.001 \\
(0.001)\end{array}$ \\
\hline Partisan*House Price & $\begin{array}{c}-0.023^{*} \\
(0.013)\end{array}$ & $\begin{array}{c}-0.027 * * \\
(0.011)\end{array}$ & $\begin{array}{c}-0.024 * * * \\
(0.009)\end{array}$ & $\begin{array}{c}-0.013 * * * \\
(0.004)\end{array}$ & $\begin{array}{c}-0.012 * * \\
(0.006)\end{array}$ & $\begin{array}{c}-0.012 * * \\
(0.006)\end{array}$ \\
\hline GDP per capita & $\begin{array}{l}-0.253 \\
(0.475)\end{array}$ & $\begin{array}{l}-0.138 \\
(0.558)\end{array}$ & $\begin{array}{c}-0.955^{* * * *} \\
(0.220)\end{array}$ & $\begin{array}{c}0.013 \\
(0.133)\end{array}$ & $\begin{array}{c}-0.087 * * * \\
(0.025)\end{array}$ & $\begin{array}{c}-0.077 * * * \\
(0.024)\end{array}$ \\
\hline GDP growth & $\begin{array}{l}-0.118^{*} \\
(0.061)\end{array}$ & $\begin{array}{c}-0.218 * * \\
(0.087)\end{array}$ & $\begin{array}{l}-0.012 \\
(0.031)\end{array}$ & $\begin{array}{c}-0.248 * * * \\
(0.018)\end{array}$ & $\begin{array}{c}-0.213 * * * \\
(0.020)\end{array}$ & $\begin{array}{c}-0.233 * * * \\
(0.021)\end{array}$ \\
\hline Population (ln) & $\begin{array}{c}2.618 \\
(9.343)\end{array}$ & $\begin{array}{c}3.178 \\
(9.358)\end{array}$ & $\begin{array}{c}3.936 \\
(8.031)\end{array}$ & $\begin{array}{c}1.903 \\
(1.628)\end{array}$ & $\begin{array}{l}-0.004 \\
(0.064)\end{array}$ & $\begin{array}{l}-0.058 \\
(0.058)\end{array}$ \\
\hline Unemployment & $\begin{array}{c}0.337 \\
(0.214)\end{array}$ & $\begin{array}{c}0.243 \\
(0.181)\end{array}$ & $\begin{array}{c}0.041 \\
(0.074)\end{array}$ & $\begin{array}{l}-0.052 \\
(0.035)\end{array}$ & $\begin{array}{l}-0.029 \\
(0.019)\end{array}$ & $\begin{array}{l}-0.016 \\
(0.016)\end{array}$ \\
\hline Real Interest rate & & $\begin{array}{c}0.078 \\
(0.102)\end{array}$ & $\begin{array}{c}0.034 \\
(0.026)\end{array}$ & $\begin{array}{c}0.086^{* *} \\
(0.031)\end{array}$ & $\begin{array}{c}0.079 * * * \\
(0.017)\end{array}$ & $\begin{array}{c}0.076 * * * \\
(0.017)\end{array}$ \\
\hline Inflation & & $\begin{array}{l}-0.124 \\
(0.126)\end{array}$ & $\begin{array}{l}-0.041 \\
(0.035)\end{array}$ & $\begin{array}{l}-0.053 \\
(0.032)\end{array}$ & $\begin{array}{l}-0.033 * \\
(0.018)\end{array}$ & $\begin{array}{c}-0.040^{* *} \\
(0.017)\end{array}$ \\
\hline Trade & & $\begin{array}{c}0.004 \\
(0.062)\end{array}$ & $\begin{array}{l}-0.004 \\
(0.018)\end{array}$ & $\begin{array}{l}-0.001 \\
(0.013)\end{array}$ & $\begin{array}{l}-0.003 \\
(0.003)\end{array}$ & $\begin{array}{l}-0.004 \\
(0.003)\end{array}$ \\
\hline Population $>65$ & & $\begin{array}{l}-0.192 \\
(0.329)\end{array}$ & $\begin{array}{l}-0.459 \\
(0.358)\end{array}$ & $\begin{array}{l}-0.050 \\
(0.056)\end{array}$ & $\begin{array}{c}0.073 * * \\
(0.033)\end{array}$ & $\begin{array}{c}0.070 * * \\
(0.032)\end{array}$ \\
\hline Constant & $\begin{array}{c}-24.649 \\
(160.094)\end{array}$ & $\begin{array}{c}-33.784 \\
(159.118)\end{array}$ & $\begin{array}{c}5.077 \\
(3.119)\end{array}$ & $\begin{array}{l}-30.323 \\
(26.679)\end{array}$ & $\begin{array}{c}2.911 * * \\
(1.235)\end{array}$ & $\begin{array}{c}96.278 * * \\
(40.231)\end{array}$ \\
\hline $\begin{array}{l}\text { Observations } \\
\text { R-squared } \\
\text { Number of ccode }\end{array}$ & $\begin{array}{c}396 \\
0.381 \\
18\end{array}$ & $\begin{array}{c}346 \\
0.424 \\
18\end{array}$ & $\begin{array}{c}328 \\
0.420 \\
18\end{array}$ & $\begin{array}{c}346 \\
0.878 \\
18\end{array}$ & $\begin{array}{c}346 \\
0.983 \\
18\end{array}$ & $\begin{array}{c}346 \\
0.986 \\
18\end{array}$ \\
\hline
\end{tabular}

All models, except Model 6, contain year dummies. Country clustered robust standard errors in parentheses $* * * \mathrm{p}<0.01, * * \mathrm{p}<0.05, * \mathrm{p}<0.1$ 
Table Eight: Effects of Partisanship and House Prices by Homeownership Rate

\begin{tabular}{|c|c|c|c|c|c|c|c|c|}
\hline & $\begin{array}{c}(1) \\
\text { SOC SP }\end{array}$ & $\begin{array}{c}(2) \\
\text { SOC SP }\end{array}$ & $\begin{array}{c}(3) \\
\text { PENS }\end{array}$ & $\begin{array}{c}(4) \\
\text { PENS }\end{array}$ & $\begin{array}{c}(5) \\
\text { UNEMP }\end{array}$ & $\begin{array}{c}(6) \\
\text { UNEMP }\end{array}$ & $\begin{array}{c}(7) \\
\text { TRANS }\end{array}$ & $\begin{array}{c}(8) \\
\text { TRANS }\end{array}$ \\
\hline & LOW & $\mathrm{HIGH}$ & LOW & $\mathrm{HIGH}$ & LOW & $\mathrm{HIGH}$ & LOW & HIGH \\
\hline Lagg & $\begin{array}{c}0.734 * * * \\
(0.091)\end{array}$ & $\begin{array}{c}0.827 * * * \\
(0.066)\end{array}$ & $\begin{array}{c}0.681^{* * * *} \\
(0.091)\end{array}$ & $\begin{array}{c}0.813 * * * \\
(0.063)\end{array}$ & $\begin{array}{c}0.522 * * * \\
(0.080)\end{array}$ & $\begin{array}{c}0.708 * * * \\
(0.083)\end{array}$ & $\begin{array}{c}0.843 * * * \\
(0.070)\end{array}$ & $\begin{array}{c}0.946^{* * *} \\
(0.048)\end{array}$ \\
\hline House Price Ch. & $\begin{array}{l}-0.582 \\
(0.470)\end{array}$ & $\begin{array}{l}-0.417 \\
(0.559)\end{array}$ & $\begin{array}{c}-0.060 \\
(0.181)\end{array}$ & $\begin{array}{l}-0.231 \\
(0.202)\end{array}$ & $\begin{array}{c}0.062 \\
(0.129)\end{array}$ & $\begin{array}{l}-0.153 \\
(0.184)\end{array}$ & $\begin{array}{l}-0.513 \\
(0.719)\end{array}$ & $\begin{array}{l}0.671 * \\
(0.357)\end{array}$ \\
\hline Partisanship & $\begin{array}{l}-0.004 \\
(0.004)\end{array}$ & $\begin{array}{l}-0.002 \\
(0.004)\end{array}$ & $\begin{array}{c}0.000 \\
(0.001)\end{array}$ & $\begin{array}{l}-0.001 \\
(0.002)\end{array}$ & $\begin{array}{l}-0.001 \\
(0.001)\end{array}$ & $\begin{array}{c}0.001 \\
(0.001)\end{array}$ & $\begin{array}{c}-0.009^{*} \\
(0.005)\end{array}$ & $\begin{array}{c}0.002 \\
(0.002)\end{array}$ \\
\hline House Pr & $\begin{array}{l}-0.014 \\
(0.010)\end{array}$ & $\begin{array}{c}-0.027 * * \\
(0.012)\end{array}$ & $\begin{array}{l}-0.001 \\
(0.004)\end{array}$ & $\begin{array}{c}-0.009 * * \\
(0.004)\end{array}$ & $\begin{array}{l}-0.003 \\
(0.002)\end{array}$ & $\begin{array}{c}-0.012 * * * \\
(0.004)\end{array}$ & $\begin{array}{l}-0.023 \\
(0.014)\end{array}$ & $\begin{array}{l}-0.015 * \\
(0.008)\end{array}$ \\
\hline GDP per capita & $\begin{array}{l}-0.279 \\
(0.208)\end{array}$ & $\begin{array}{l}0.286^{*} \\
(0.145)\end{array}$ & $\begin{array}{l}-0.051 \\
(0.082)\end{array}$ & $\begin{array}{l}0.091^{*} \\
(0.055)\end{array}$ & $\begin{array}{c}-0.107 * * \\
(0.051)\end{array}$ & $\begin{array}{c}0.064 \\
(0.049)\end{array}$ & $\begin{array}{l}-0.248 \\
(0.241)\end{array}$ & $\begin{array}{c}0.056 \\
(0.114)\end{array}$ \\
\hline GDP growth & $\begin{array}{l}-0.103 * \\
(0.059)\end{array}$ & $\begin{array}{c}-0.282 * * * \\
(0.039)\end{array}$ & $\begin{array}{c}-0.045 * \\
(0.023)\end{array}$ & $\begin{array}{c}-0.072 * * * \\
(0.014)\end{array}$ & $\begin{array}{l}-0.002 \\
(0.016)\end{array}$ & $\begin{array}{c}-0.078 * * * \\
(0.014)\end{array}$ & $\begin{array}{c}-0.233 * * * \\
(0.081)\end{array}$ & $\begin{array}{c}-0.231 * * * \\
(0.028)\end{array}$ \\
\hline Population (ln) & $\begin{array}{c}-13.198 \\
(11.327)\end{array}$ & $\begin{array}{l}-0.113 \\
(3.933)\end{array}$ & $\begin{array}{l}-6.939 \\
(4.325)\end{array}$ & $\begin{array}{l}-0.089 \\
(1.444)\end{array}$ & $\begin{array}{l}-1.326 \\
(2.652)\end{array}$ & $\begin{array}{c}-3.147 * * \\
(1.497)\end{array}$ & $\begin{array}{l}-13.792 \\
(10.448)\end{array}$ & $\begin{array}{l}2.516 \\
(2.664)\end{array}$ \\
\hline Unem & $\begin{array}{c}0.017 \\
(0.083)\end{array}$ & $\begin{array}{c}0.016 \\
(0.074)\end{array}$ & $\begin{array}{c}0.030 \\
(0.030)\end{array}$ & $\begin{array}{c}0.003 \\
(0.026)\end{array}$ & $\begin{array}{c}0.119 * * * \\
(0.024)\end{array}$ & $\begin{array}{c}0.045 \\
(0.028)\end{array}$ & $\begin{array}{l}-0.022 \\
(0.092)\end{array}$ & $\begin{array}{c}0.011 \\
(0.043)\end{array}$ \\
\hline Real Interest rate & $\begin{array}{c}0.155^{* *} \\
(0.061)\end{array}$ & $\begin{array}{c}0.083 * * \\
(0.038)\end{array}$ & $\begin{array}{l}0.043 * \\
(0.022)\end{array}$ & $\begin{array}{c}0.009 \\
(0.014)\end{array}$ & $\begin{array}{c}0.019 \\
(0.013)\end{array}$ & $\begin{array}{c}0.028 * * \\
(0.011)\end{array}$ & $\begin{array}{c}0.217 * * * \\
(0.075)\end{array}$ & $\begin{array}{l}0.039^{*} \\
(0.023)\end{array}$ \\
\hline Inflation & $\begin{array}{c}0.014 \\
(0.081)\end{array}$ & $\begin{array}{l}-0.012 \\
(0.049)\end{array}$ & $\begin{array}{l}-0.010 \\
(0.031)\end{array}$ & $\begin{array}{c}0.001 \\
(0.018)\end{array}$ & $\begin{array}{l}0.037^{*} \\
(0.019)\end{array}$ & $\begin{array}{l}-0.007 \\
(0.018)\end{array}$ & $\begin{array}{l}-0.090 \\
(0.076)\end{array}$ & $\begin{array}{c}0.033 \\
(0.031)\end{array}$ \\
\hline Trade & $\begin{array}{l}-0.048^{*} \\
(0.026)\end{array}$ & $\begin{array}{l}-0.013 \\
(0.017)\end{array}$ & $\begin{array}{l}-0.016 \\
(0.010)\end{array}$ & $\begin{array}{l}-0.003 \\
(0.006)\end{array}$ & $\begin{array}{c}-0.021^{* * * *} \\
(0.006)\end{array}$ & $\begin{array}{c}0.001 \\
(0.006)\end{array}$ & $\begin{array}{l}-0.036 \\
(0.035)\end{array}$ & $\begin{array}{c}0.002 \\
(0.014)\end{array}$ \\
\hline Population $>65$ & $\begin{array}{c}0.010 \\
(0.198)\end{array}$ & $\begin{array}{c}0.281 \\
(0.269)\end{array}$ & $\begin{array}{c}0.031 \\
(0.074)\end{array}$ & $\begin{array}{c}0.321 * * \\
(0.124)\end{array}$ & $\begin{array}{c}0.005 \\
(0.046)\end{array}$ & $\begin{array}{l}-0.050 \\
(0.096)\end{array}$ & $\begin{array}{c}0.027 \\
(0.308)\end{array}$ & $\begin{array}{c}-0.345^{* * *} \\
(0.122)\end{array}$ \\
\hline Homeownership & $\begin{array}{l}-0.093^{*} \\
(0.049)\end{array}$ & $\begin{array}{l}-0.105 \\
(0.071)\end{array}$ & $\begin{array}{c}0.003 \\
(0.019)\end{array}$ & $\begin{array}{l}-0.015 \\
(0.026)\end{array}$ & $\begin{array}{l}-0.013 \\
(0.011)\end{array}$ & $\begin{array}{l}-0.019 \\
(0.023)\end{array}$ & $\begin{array}{l}-0.084 \\
(0.063)\end{array}$ & $\begin{array}{l}-0.047 \\
(0.037)\end{array}$ \\
\hline Constant & $\begin{array}{c}237.965 \\
(190.090)\end{array}$ & $\begin{array}{c}5.423 \\
(67.180)\end{array}$ & $\begin{array}{c}118.937 \\
(72.369)\end{array}$ & $\begin{array}{c}-1.230 \\
(24.768)\end{array}$ & $\begin{array}{c}25.902 \\
(44.308)\end{array}$ & $\begin{array}{c}52.745 * * \\
(25.551)\end{array}$ & $\begin{array}{c}245.658 \\
(176.056)\end{array}$ & $\begin{array}{l}-34.245 \\
(45.415)\end{array}$ \\
\hline Observations & 107 & 124 & 107 & 124 & 107 & 122 & 131 & 156 \\
\hline R-squared & 0.910 & 0.943 & 0.888 & 0.913 & 0.948 & 0.920 & 0.872 & 0.955 \\
\hline Countries & 7 & 8 & 7 & 8 & 7 & 8 & 7 & 8 \\
\hline
\end{tabular}


Table Nine: Capital Flows, House Prices, Partisanship, and Public Spending

\begin{tabular}{|c|c|c|c|c|}
\hline & $\begin{array}{c}(1) \\
\text { House Price Change } \\
\text { ALL } \\
\end{array}$ & $\begin{array}{c}(2) \\
\text { House Price Change } \\
\text { ALL } \\
\end{array}$ & $\begin{array}{c}(3) \\
\text { Social Spending } \\
\text { CUR ACCT DEF. }\end{array}$ & $\begin{array}{c}\text { (4) } \\
\text { Social Spending } \\
\text { CURR ACCT SUR. }\end{array}$ \\
\hline Partisanship & $\begin{array}{c}0.001 \\
(0.000)\end{array}$ & $\begin{array}{c}0.001^{* * *} \\
(0.000)\end{array}$ & $\begin{array}{c}0.009 \\
(0.006)\end{array}$ & $\begin{array}{l}-0.003 \\
(0.005)\end{array}$ \\
\hline House Price Ch. & & & $\begin{array}{c}0.599 \\
(0.705)\end{array}$ & $\begin{array}{c}-2.593^{* * *} \\
(0.591)\end{array}$ \\
\hline Partisanship*HP & & & $\begin{array}{l}-0.043^{* *} \\
(0.016)\end{array}$ & $\begin{array}{c}-0.023 \\
(0.017)\end{array}$ \\
\hline Current Account & $\begin{array}{c}-0.020^{* * *} \\
(0.006)\end{array}$ & $\begin{array}{c}-0.018^{* * *} \\
(0.003)\end{array}$ & & \\
\hline GDP per capita & $\begin{array}{c}0.038 \\
(0.033)\end{array}$ & $\begin{array}{c}0.016 \\
(0.014)\end{array}$ & $\begin{array}{c}0.091 \\
(0.230)\end{array}$ & $\begin{array}{l}-0.039 \\
(0.182)\end{array}$ \\
\hline GDP Growth & $\begin{array}{c}0.002 \\
(0.006)\end{array}$ & $\begin{array}{c}-0.002 \\
(0.003)\end{array}$ & $\begin{array}{c}-0.276^{* * *} \\
(0.069)\end{array}$ & $\begin{array}{c}-0.184^{* * *} \\
(0.068)\end{array}$ \\
\hline Population & $\begin{array}{l}4.033^{* *} \\
(1.450)\end{array}$ & $\begin{array}{l}2.255^{* *} \\
(0.898)\end{array}$ & $\begin{array}{l}3.106 \\
(7.013)\end{array}$ & $\begin{array}{l}9.613^{*} \\
(5.735)\end{array}$ \\
\hline Unemployment & $\begin{array}{l}-0.031^{*} \\
(0.016)\end{array}$ & $\begin{array}{c}-0.027^{* * *} \\
(0.004)\end{array}$ & $\begin{array}{l}0.577^{* * *} \\
(0.129)\end{array}$ & $\begin{array}{l}0.365^{* * *} \\
(0.080)\end{array}$ \\
\hline Interest Rate & $\begin{array}{c}0.003 \\
(0.004)\end{array}$ & $\begin{array}{c}0.001 \\
(0.003)\end{array}$ & $\begin{array}{c}0.089 \\
(0.063)\end{array}$ & $\begin{array}{l}0.120^{*} \\
(0.069)\end{array}$ \\
\hline Inflation & $\begin{array}{c}0.001 \\
(0.005)\end{array}$ & $\begin{array}{c}0.001 \\
(0.003)\end{array}$ & $\begin{array}{c}0.077 \\
(0.063)\end{array}$ & $\begin{array}{l}-0.134 \\
(0.083)\end{array}$ \\
\hline Openness & $\begin{array}{l}-0.004^{*} \\
(0.002)\end{array}$ & $\begin{array}{l}-0.001 \\
(0.001)\end{array}$ & $\begin{array}{c}0.028 \\
(0.039)\end{array}$ & $\begin{array}{l}-0.051^{* *} \\
(0.022)\end{array}$ \\
\hline Over 65 & $\begin{array}{c}0.035 \\
(0.048)\end{array}$ & $\begin{array}{c}0.027 \\
(0.017)\end{array}$ & $\begin{array}{l}-0.370^{*} \\
(0.215)\end{array}$ & $\begin{array}{c}0.014 \\
(0.168)\end{array}$ \\
\hline House Price Lev. & & $\begin{array}{c}-0.005^{* * *} \\
(0.000)\end{array}$ & & \\
\hline Constant & $\begin{array}{c}-0.091 \\
(0.155) \\
\end{array}$ & $\begin{array}{c}0.616^{* * *} \\
(0.100) \\
\end{array}$ & $\begin{array}{c}-37.232 \\
(117.962) \\
\end{array}$ & $\begin{array}{l}-138.325 \\
(95.636) \\
\end{array}$ \\
\hline$N$ & 285 & 285 & 127 & 171 \\
\hline
\end{tabular}

Columns 1 and 2 use five year changes for all IVs and use house price change as DV. Columns 3 and 4 use levels for all IVs as in Tables Seven and Eight and use total social spending as DV.

Standard errors in parentheses ${ }^{*} p<.1,{ }^{* *} p<.05,{ }^{* * *} p<.01$ 
Figure One (a): Estimated Effects of House Price Changes on Total Social Spending

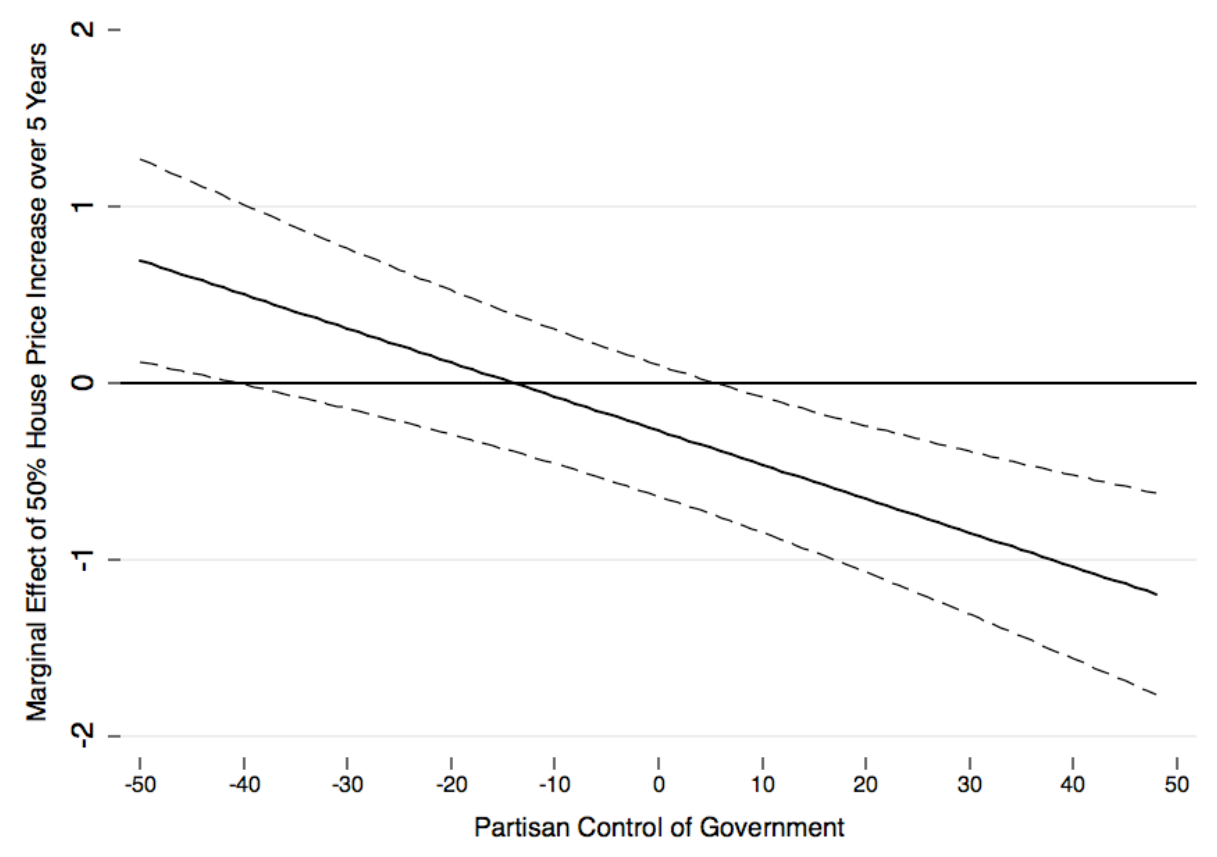

Figure One (b): Estimated Effects of House Price Changes on Pensions Spending

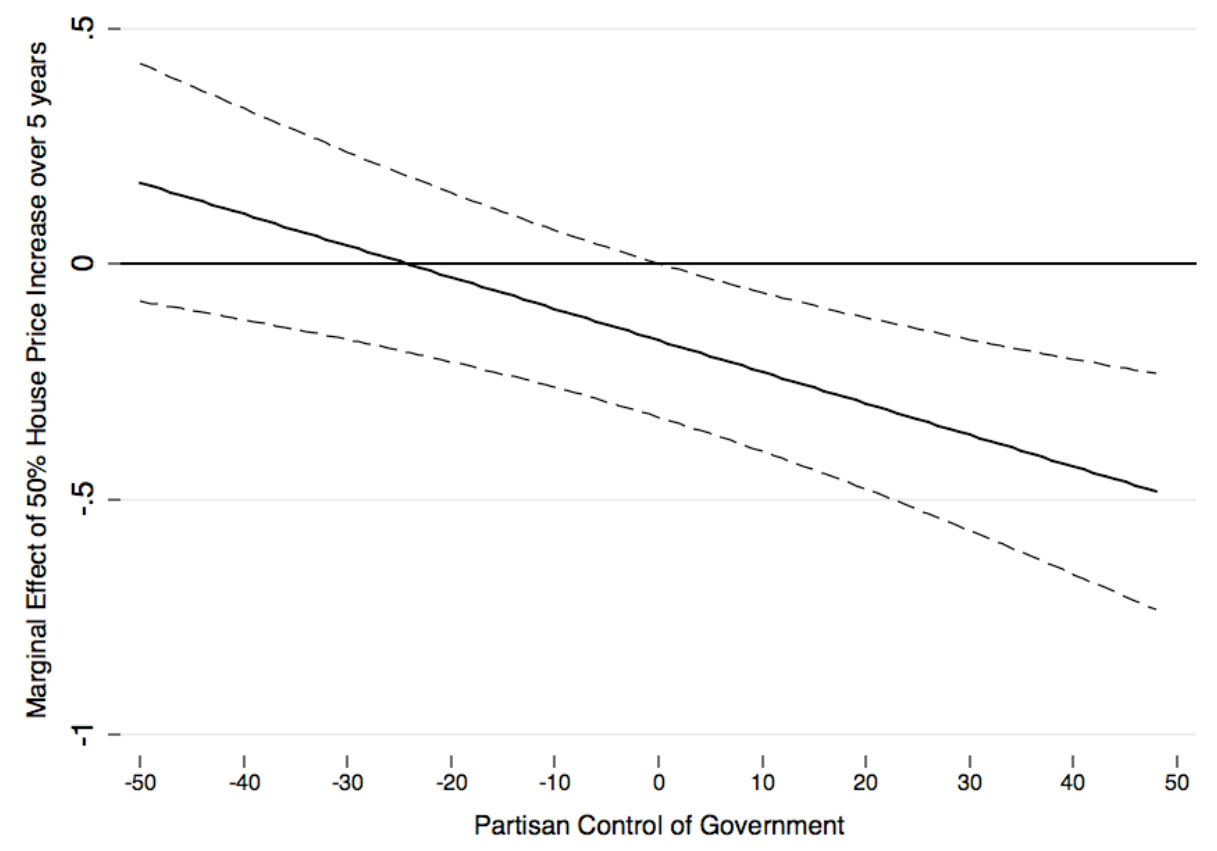


Figure Two (a) Partisanship, Housing, and Public Spending in Capital Inflow Countries

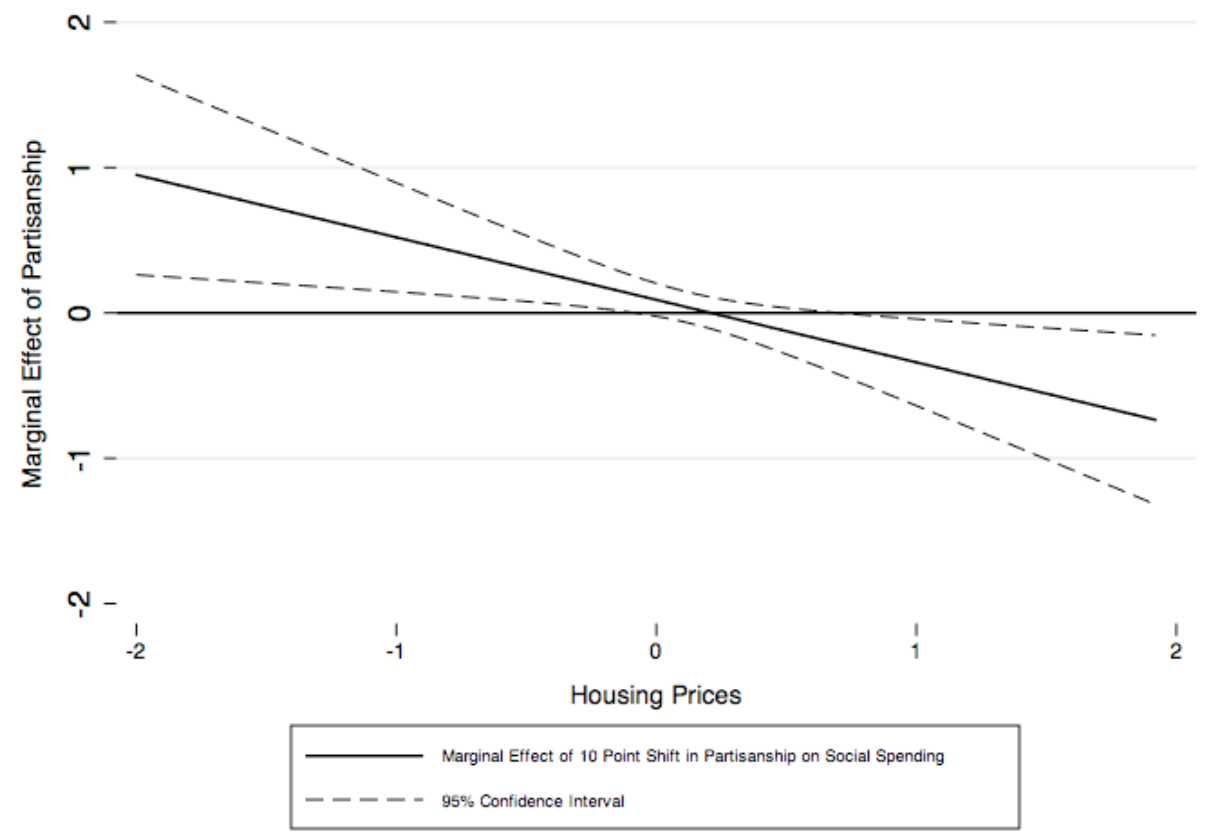

Figure Two (a) Partisanship, Housing, and Public Spending in Capital Outflow Countries

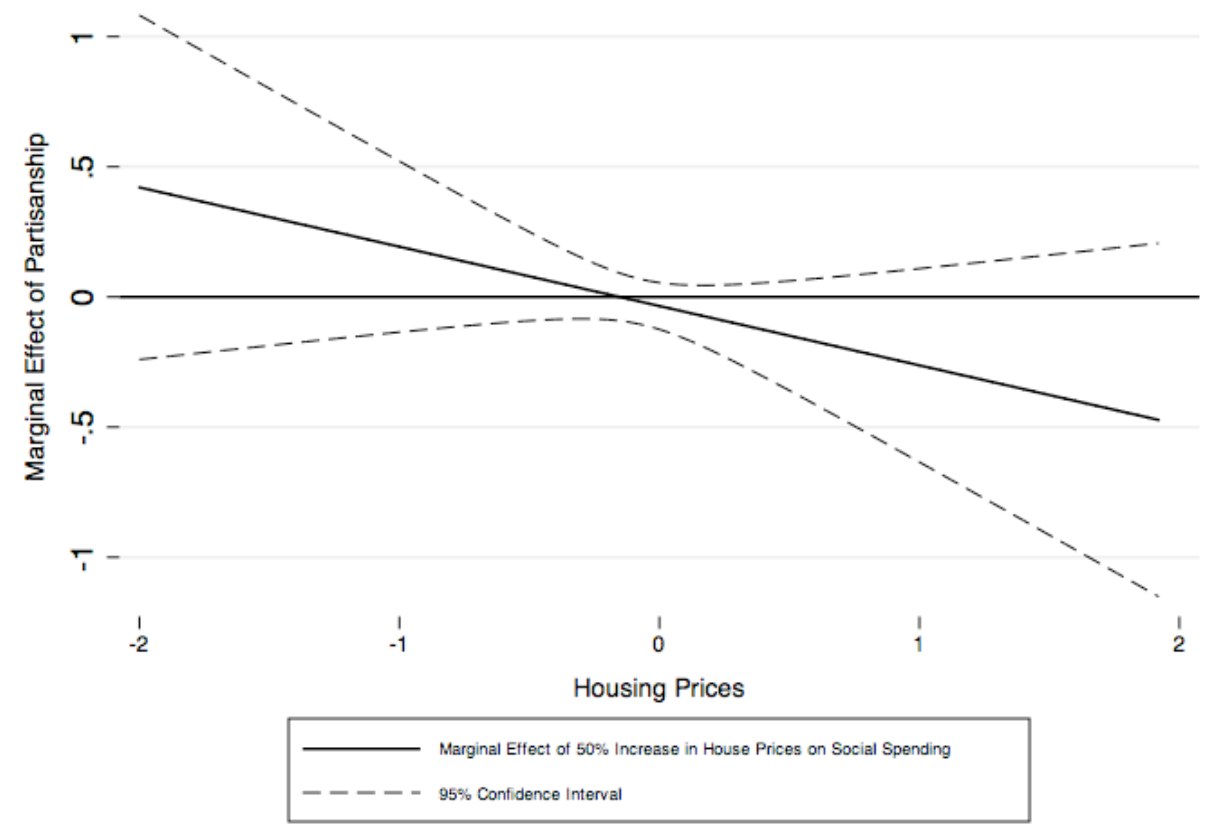


${ }^{\mathrm{i}}$ Sometimes, of course, this evaluation may be off-base or irrationally formed (Shiller, 2006). In this case citizens may hold policy beliefs that reflect their false impressions of the value of their house as opposed to its fundamental long-run value.

${ }^{\text {ii }}$ In the BSAS 2001, for each type of program, some respondents were asked if taxes should go up one penny in the pound to pay for these programs, whereas some were asked if taxes should go up three pennies in the pound. I combine these groups into one indicator for pensions and one for unemployment, though similar patterns hold within each group. In the BSAS 2006 the questions are simply whether the government should increase spending on pensions or unemployment respectively.

iii Using dummies for political parties produces very similar results, though the existence of a viable third party makes results for partisanship less clear than the US case.

${ }^{\text {iv }}$ For the BSAS 2006, I used the Goldthorpe occupational dummies that unlike ISCO codes are included in the dataset. These are not perfect substitutes, see Iversen (2008).

${ }^{v}$ These two parties mark the clearest left-right dimension in British politics, with the Liberal Democrats and regional parties having less well-defined preferences over social insurance, though they typically lean to the left.

vi This means excluding non-voters, and voters for the small regional parties, including Northern Ireland. Results are similar if dummies for changes in membership of these parties are added.

${ }^{\text {vii }}$ Using different lengths of time produces similar results, including one year changes. However, a five year period is both shorter than most housing booms but avoids the volatility of a one year indicator and is less likely to cause endogeneity problems.

viii This configuration of sources provides the greatest time and country coverage. Other measures of unemployment and GDP provide very similar results on a truncated dataset.

${ }^{\text {ix }}$ These variables along with the dependent variables were drawn from the Quality of Governance Social Policy dataset compiled by Samanni et al (2008). 
${ }^{\mathrm{x}}$ Results not shown, available from author.

${ }^{x i}$ Using different models alters the slope and intercept of these predicted curves though broadly the substantive interpretation is the same.

xii That the $\mathrm{x}$-axis reflects swings of partisanship within countries rather than levels across countries is due to the use of country dummies.

xiii Atterhog's data is collected at different time intervals across countries: sometimes every year, sometimes every five years. In order to have uniform data I linearly interpolate home ownership rates for missing years - since homeownership rates are slow-moving this introduces limited bias. ${ }^{\text {xiv }}$ Introducing the homeownership rate as an extra control variable into Tables Five (a) through (d) has minimal effects on the coefficients of interest but reduces the number of cases substantially. Results available from author.

${ }^{\mathrm{xv}}$ This finding mirrors that found in the analysis of German survey data where homeownership at the individual level was a robust predictor of social policy preferences but changes in house prices were less robust, as compared to the UK and American cases. Germany has much lower rates of home ownership than these two countries. 